\title{
Effectiveness of treatment and diversity of microbial populations within a constructed wetland treating wastewater
}

Jolene M. Friedland

West Virginia University

Follow this and additional works at: https://researchrepository.wvu.edu/etd

\section{Recommended Citation}

Friedland, Jolene M., "Effectiveness of treatment and diversity of microbial populations within a constructed wetland treating wastewater" (2004). Graduate Theses, Dissertations, and Problem Reports. 2040.

https://researchrepository.wvu.edu/etd/2040

This Thesis is protected by copyright and/or related rights. It has been brought to you by the The Research Repository @ WVU with permission from the rights-holder(s). You are free to use this Thesis in any way that is permitted by the copyright and related rights legislation that applies to your use. For other uses you must obtain permission from the rights-holder(s) directly, unless additional rights are indicated by a Creative Commons license in the record and/ or on the work itself. This Thesis has been accepted for inclusion in WVU Graduate Theses, Dissertations, and Problem Reports collection by an authorized administrator of The Research Repository @ WVU. For more information, please contact researchrepository@mail.wvu.edu. 
EFFECTIVENESS OF TREATMENT AND DIVERSITY OF MICROBIAL

POPULATIONS WITHIN A CONSTRUCTED WETLAN D TREATING WASTEWATER

by

Jolene M Friedland

Thesis submitted to the Davis College of Agriculture, Forestry, and Consumer Sciences at West Virginia University

in partial fulfillment of the requirements

for the degree of

Master of Science

in

Plant and Soil Sciences with a concentration in Environmental Microbiology

Approved by

Alan Sexstone, Ph.D., Committee Chairperson

Gary Bissonnette, Ph.D.

Jeffrey Skousen, Ph.D.

Department of Plant Pathology and E nvironmental Microbiology

Morgantown, West Virginia

2004

Keywords: Constructed wetland, wastewater, $\mathrm{BOD}_{5}$, TSS, fecal coliforms, CLPP, PCR, DGGE 


\begin{abstract}
EFFECTIVENESS OF TREATMENT AND DIVERSITY OF MICROBIAL POPULATIONS WITHIN A CONSTRUCTED WETLAND TREATING WASTEWATER

by Jolene M Friedland

Constructed wetlands are used as alternative on-site wastewater treatment systems. Microbiological dynamics in constructed wetlands are essential to adequate functioning and efficiency of these systems. The efficacy of wastewater treatment by a large subsurface flow wetland receiving wastewater from a multi-user facility was examined. Real-time monitoring with telemetry was combined with measurement of standard wastewater parameters such as biochemical oxygen demand (BO D 5 ), total suspended solids (TSS), and enumeration of fecal coliforms. Passage of wastewater through the wetland significantly reduced standard wastewater parameters in effluent samples. Heterotrophic bacterial diversity was examined using community level physiological profiling (CLPP) and molecular characterization of $16 \mathrm{~S}$ ribosomal RNA genes by polymerase chain reaction (PCR) and denaturing gradient gel electrophoresis (DGGE). Principal component analysis (PCA) indicated distinct grouping between the influent and effluent wastewater populations while D G GE analysis indicated distinct groupings according to cell size.
\end{abstract}




\section{Acknowledgments}

I wish to acknowledge the United States Environmental Protection Agency (USEPA) and the National O n-site D emonstration Project (NODP) for providing funding for this research. Additionally I would like to thank the West Virginia University Division of Plant \& Soil Sciences for providing additional funding. I would also like to extend thanks to my committee members: D r. Alan Sexstone, D r. G ary Bissonnette, and D r. Jeffrey Skousen. The knowledge you have shared with me along with all your help with my research is greatly appreciated. 


\section{TABLE OF CONTENTS}

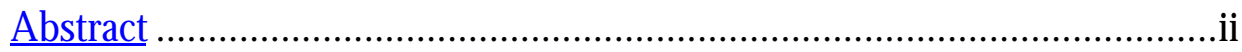

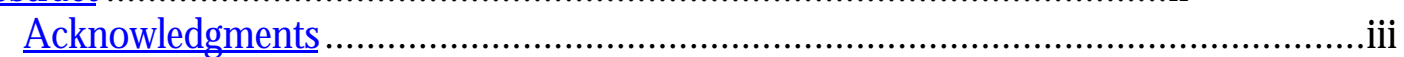

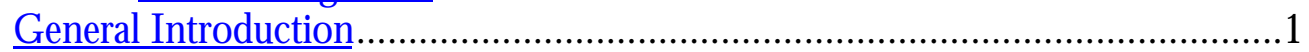

Reference List.................................................................................................

Chapter 1: real-time monitoring and seasonal effectiveness of a subsurface flow constructed wetland treating wastewater from a large multi-user facility...................................4

Introduction........................................................................................

Materials and Methods................................................................................

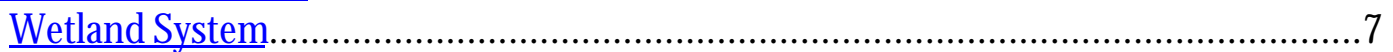

Telemetry Configuration ..................................................................................

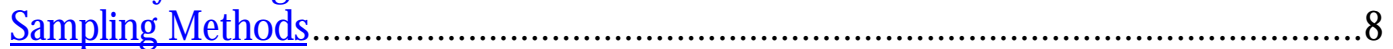

Physical and Chemical Analyses........................................................................

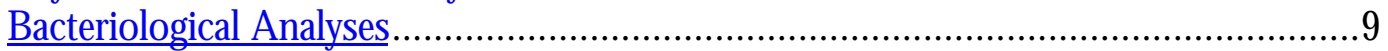

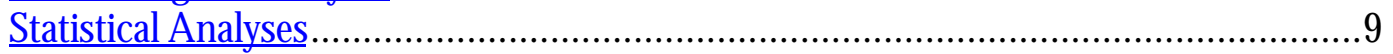

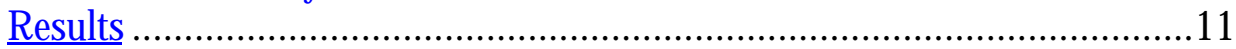

Comparison of Telemetry with Conventional Sampling...........................................11

Seasonal Performance of the Wetland Treatment System...........................................12

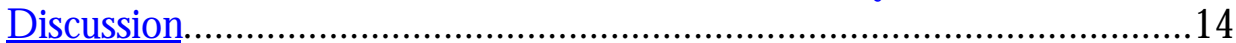

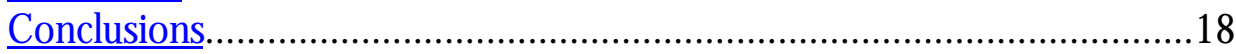

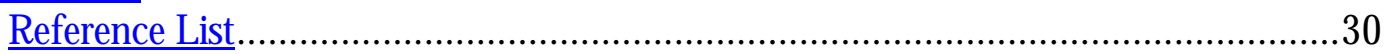

Chapter 2: bacterial diversity within a constructed wetland treating wastewater: A case study33

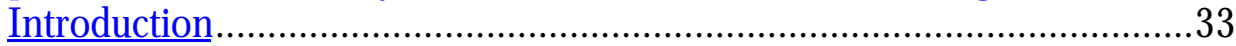

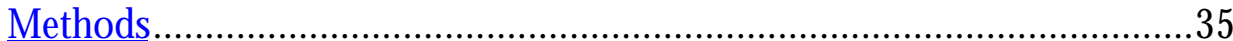

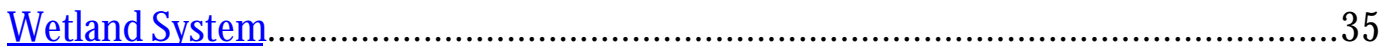

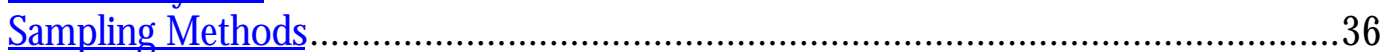

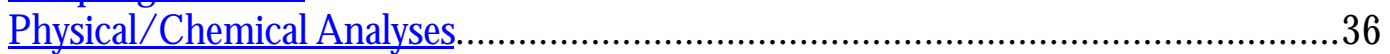

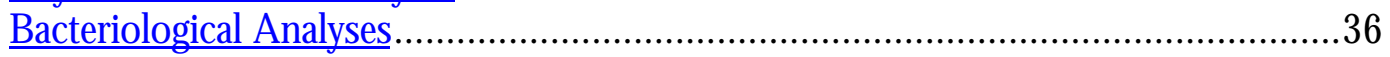

Sample Preparation for Culture-D ependent and Culture-Independent Analyses.........37

Inoculation and Reading of BIO LO G Plates............................................................37

Denaturing G radient G el Electrophoresis (DGGE) ...............................................37

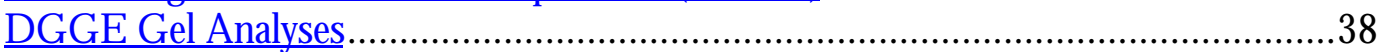

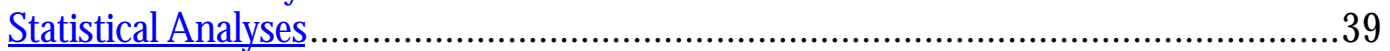

Results and Discussion ..........................................................................40

Physical, Chemical, and Bacteriological Analyses .....................................................40

Community-Level Physiological Profiles ..................................................................40

Denaturing G radient G el Electrophoresis Analyses...................................................4

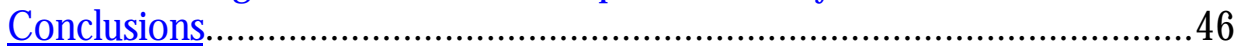

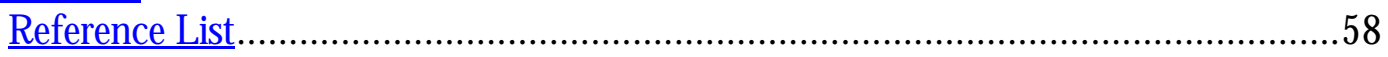




\section{LIST OF TABLES}

\section{Chapter 1}

Table 1. Telemetric measurement of wetland parameters averaged over differing sampling periods during summer months .............................................................................19

Table 2. Physical/ chemical parameters and microbial densities of primary clarified wetland influent and wetland effluent over 7-day intensive sampling period............................20

Table 3. Physical and chemical parameters of primary clarified wetland influent and wetland effluent during winter compared to summer...........................................................21

Table 4. Microbial densities of primary clarified wetland influent and wetland effluent during winter compared to summer...........................................................................22

\section{Chapter 2}

Table 1. Physical and chemical parameters and microbial densities of primary clarified wetland influent and wetland effluent over entire sampling period ............................47

Table 2. Bacterial functional diversity indices as determined with BIO LOG $®$ ECO plates..48

Table 3. Richness within substrate guilds as determined by strongly utilized substrates with BIOLOG $®$ ECO plates

Table 4. Bacterial diversity indices as determined with DG GE profiles ...................................50 


\section{LIST OF FIGURES}

\section{Chapter 1}

Figure 1. General schematic of the constructed subsurface flow wetland system. .23

Figure 2. D aily averages for telemetric readings of $\mathrm{pH}$, wetland temperature, air temperature, and dissolved oxygen recorded over summer period.. 24

Figure 3. Daily averages for calculated hydraulic loading rate and hydraulic retention time recorded over summer period...............................................................................25

Figure 4. D aily averages for telemetric readings of $\mathrm{pH}$, wetland temperature, air temperature, and dissolved oxygen recorded during August..

Figure 5. Daily averages for calculated hydraulic loading rate and hydraulic retention time

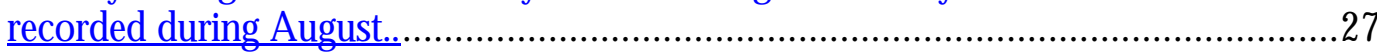

Figure 6. Daily averages for calculated hydraulic loading rate and hydraulic retention time recorded during 7-day sampling. .............................................................................28

Figure 7. D aily averages for conventional analysis of influent and effluent $\mathrm{BOD}_{5}$ and TSS measured over 7-day sampling period.

\section{Chapter 2}

Figure 1. General schematic of the constructed subsurface flow wetland system .51

Figure 2. Average well color development (AWCD) from BIOLOG @ ECO plates for the total cell (TC) fraction using culture-independent (CI) analysis and the large cell (LC) and small cell (SC) fractions using culture-dependent analysis

Figure 3. Principal component analysis based on normalized AWCD (average absorbance value for each substrate divided by AWCD) from BIOLOG ® ECO plates ...............53

Figure 4. Principal component analysis based on normalized AWCD (average absorbance value for each substrate divided by AWCD) from BIOLOG ® ECO plates for the total cell (TC) fraction using culture-independent (CI) analysis.

Figure 5. D GGE analysis of PCR-amplified 16S rRNA genes from the LC and SC fractions of the wetland bacterial communities

Figure 6. Unweighted (a) UPGMA and weighted (b) UPG MA dendrograms constructed using dice similarity matrix generated from D GGE profiles of PCR-amplified $16 \mathrm{~S}$ rRNA genes from the LC and SC fractions of the wetland bacterial communities.......56

Figure 7. Principal component analysis based on normalized band intensity (band intensity value for each band divided by total lane intensity) from D G GE analysis of PCRamplified 16S rRNA genes. 


\section{LIST OF APPENDICES}

Appendix 1. Photographs of Constructed Subsurface Flow Wetland Research Site ..............62 


\section{G E N E R A L I N T R O D U C T I O N}

Constructed wetlands are now in use as alternative on-site wastewater treatment systems. Constructed wetlands can reduce wastewater pollutants from a variety of sources including individual households, small towns, urban storm water runoff, agricultural point and nonpoint sources, landfill leachate, mine drainage, and water containing organic micropollutants (2). Effectiveness of wastewater treatment within constructed subsurface flow wetland systems is usually evaluated by estimating removal rates of organic matter, suspended solids, nutrients, and bacteria (especially Escheidia cdi and other coliforms) (3). Bacteria play a central role in the wastewater treatment process within constructed subsurface flow wetlands. They dominate both in numbers and biomass, and regulate mineralization and immobilization of organic and inorganic nutrients (1). The physiology, survival strategies, and community structure of bacterial populations in constructed subsurface flow wetland systems have not been extensively studied. A better understanding of bacterial dynamics in these systems will contribute to improved system design, functioning, and efficiency of constructed subsurface flow wetland systems.

In the current research, a polyphasic approach was used to evaluate treatment effectiveness and maintenance compliance of an on-site subsurface flow constructed wetland serving a large multi-user facility. Standard analyses of physical and chemical parameters, total heterotrophic bacteria, and indicator organisms were performed. The objective was to determine whether passage of primary clarified wastewater through the constructed wetland system resulted in regulatory compliance and if significant differences in treatment effectiveness were observed between winter and summer months. In-situreal-time telemetry (continuous automatic measurement and transmission) also was used to measure hydraulic loading rate of primary clarified wastewater to the wetland system, effluent discharge from the wetland system to the soil drain field, pH, dissolved oxygen (D .O .), wetland water temperature, and ambient air temperature. The objective was to gain information about changes in hydrology and insitu physical and chemical parameters of the on-site wastewater treatment system and to explore possible correlations of telemetry with results from conventional sampling. Community-level physiological profiles (CLPP) of the total cell (TC), large cell (LC), and small cell (SC) fractions 
of heterotrophic bacteria community were determined using BIO LOG® ECO plates. In addition, the genetic diversity of the bacterial community was determined by denaturing gradient gel electrophoresis (D G GE) of polymerase chain reaction (PCR) amplified 16S rRNA genes. The objective was to compare functional diversity and genetic diversity of the bacterial community within the wetland system. 


\section{Reference List}

1 Amann, R., H. Lemmer, and M. Wagner. 1998. Monitoring the community structure of wastewater treatment plants: a comparison of old and new techniques. FEMS Microbiology E cology 25:205-215.

2 Bastian, R. K. and D. A. Hammer. 1989. The use of constructed wetlands for wastewater treatment and recycling, p. 59-68. InConstructed Wetlands for Water Q uality Treatment. CRC Press, Boca Raton, FL.

3 Decamp, 0. and A. Wamen. 2001. A bundance, biomass, and viability of bacteria in wastewaters: impact of treatment in horizontal subsurface flow constructed wetlands. Water Research 35:3496-3501. 
CHAPTER 1: REAL-TIME MONITORING AND SEASONAL EFFECTIVENESS OF A SUBSURFACE FLOW CONSTRUCTED WETLAND TREATING WASTEWATER FROM A LARGE MULTI-USER FACILITY

\section{INTRO DUCTION}

According to the 1990 U.S. Census, more than 1.1 million households nationwide lack public sewerage, a septic tank, or a cesspool (26). In Appalachia and locally in West Virginia, many households and rural communities lack centralized wastewater collection and treatment facilities due to the mountainous terrain, low population densities or a lack of financial resources (9). In this case, where centralized systems are unavailable, a septic tank with a soil drain field is the most common alternative. However, installation of a septic tank with a soil drain field capable of effective treatment is not always feasible due to poor site conditions such as steep topography, low soil percolation, and limited availability of land. In the U.S., where decentralized systems serve approximately $25 \%$ of the population, septic tank effluent is the most frequently reported source of pathogenic groundwater contamination (27). Therefore, there is a need for alternative and cost-effective on-site treatment systems.

Subsurface flow constructed wetlands currently are used as alternative on-site treatment systems in West Virginia. Constructed wetlands are permitted and regulated by the West Virginia D epartment of Environmental Protection (WVDEP), Division of Water and Waste Management (DWWM). In West Virginia, constructed wetlands currently are classified as experimental treatment systems due to the lack of approved design standards and the limited information on operations and problems with existing installations. The WVDEP average monthly discharge limitations for alternative systems are $30 \mathrm{mgL}^{-1} \mathrm{BOD}_{5}, 30 \mathrm{mgL}^{-1} \mathrm{TSS}$, and $200 \mathrm{CFU} 100 \mathrm{~mL}^{-1}$ fecal coliforms; maximum daily discharge limitations are $60 \mathrm{mgL}^{-1} \mathrm{BOD}_{5}$, $60 \mathrm{mgL}^{-1} \mathrm{TSS}$, and $400 \mathrm{CFU} 100 \mathrm{~mL}^{-1}$ fecal coliforms; and instantaneous maximum discharge limitations are $75 \mathrm{mgL}^{-1} \mathrm{BOD}_{5}, 75 \mathrm{mgL}^{-1} \mathrm{TSS}$, and $500 \mathrm{CFU} 100 \mathrm{~mL}^{-1}$ fecal coliforms. Additionally, the $\mathrm{pH}$ of the discharge must be in the range of 6.0 to 9.0 standard units. These 
standards often are not met by alternative treatment systems, including both constructed wetlands and aerobic treatment units (ATUs) $(16,20,25)$.

Constructed wetlands have been used to treat wastewater sources ranging in size from individual households to small towns $(5,6)$. Subsurface flow wetlands consist of channels or basins that contain substrate (predominantly sand, gravel, or mixtures) that support growth of emergent vegetation such as cattails (Typhasp), bulrushes (Scripussp), reeds (Phragnitessp), rushes (Jumussp) and sedges (Carex sp) $(6,18,23)$. Primary clarified wastewater effluent, often from a septic tank, discharges a few inches below the surface of the substrate. Wastewater flows horizontally through the substrate, is collected in an outlet pipe, then released to a soil drain field, or disinfected with chlorine prior to direct discharge into a receiving stream. Subsurface flow wetlands decrease mosquito breeding, objectionable odors, and the possibility of human/ animal contact with partially treated wastewater.

Wastewater treatment efficiency within constructed subsurface flow wetland systems usually is assessed by estimating removal rates of organic matter, suspended solids, and coliform bacteria (12). Pollutants are removed by a variety of mechanisms, including both aerobic and anaerobic microbial processes, sorption, sedimentation, volatilization, and chemical transformations. O rganic compounds are removed through settling, entrapment of particle matter in void spaces, and microbial growth on the substrate surface and plant roots and rhizomes (11). Bacteria are removed by physical factors - filtration, sedimentation, and aggregation; biological mechanisms - antibiosis, ingestion by nematodes, protozoan, lytic bacteria and bacteriophage, and chemical factors- oxidation, adsorption, and exposure to toxins given off by other microorganisms and plants (21).

Bacteria play a central role in the wastewater treatment process within constructed subsurface flow wetlands. They dominate both in numbers and biomass, and regulate mineralization and immobilization of organic and inorganic nutrients (1). Enumeration of fecal indicator bacteria (coliforms) always has been a critical part of sanitary evaluation (29). Two-thirds of all states use fecal coliforms to monitor the quality of both fresh and marine waters (29). E. cdi also has been demonstrated to be a specific indicator for the presence of fecal contamination (13). 
Enterococci also are useful indicators of microbiological water quality since they are common inhabitants of the intestinal tracts of humans and lower animals (15). Total heterotrophic bacteria recently have been implicated as potential opportunistic pathogens in drinking water (24).

In this research, studies were performed to evaluate treatment effectiveness and maintenance compliance of an intensely utilized subsurface flow constructed wetland treating wastewater from a large multi-user facility. Analyses of physical and chemical parameters, total heterotrophic bacteria, and indicator organisms were performed. The objectives were to determine whether passage of primary clarified wastewater through the constructed wetland system consistently resulted in significant treatment and whether significant differences were observed between winter as compared to summer months. D uring summer months insitu real-time telemetry (continuous automatic measurement and transmission) also was used to measure hydraulic loading rate of wastewater to the wetland system, effluent discharge from the wetland system to the soil drain field, $\mathrm{pH}$, dissolved oxygen (D O), wetland water temperature, and ambient air temperature. Possible correlations were examined between telemetry measurements and those obtained with conventional sampling. 


\section{MATERIALS AND METHODS}

Wetland System

The system investigated was a constructed subsurface flow gravel wetland $(\sim 11.89 \mathrm{~m} \times 5.49 \mathrm{~m}$ $\mathrm{x} 0.45 \mathrm{~m}$ ) treating primary clarified wastewater from a two-compartment septic tank (Tank 1 $5678 \mathrm{~L}$ and Tank $21893 \mathrm{~L}$ ) discharging from a multi-user church facility (Figure 1). The second compartment of the septic tank acted as a dosing tank for the wetland. The number of users attending the facility varied throughout the week and also throughout the study period; however, the maximum number of users was always on Sunday. It was estimated approximately 1300 people were present on Sundays, with numbers during the remainder of the week ranging from 10-250 depending on on-going programs and functions. The wetland was constructed with $1.3 \mathrm{~cm}$ gravel (approximately 44\% porosity - based on field testing), lined with a $50 \mathrm{~mm}$ flexible liner, and the area surrounding the wetland was constructed with larger stone to limit overland runoff to the wetland. The slope of the wetland was approximately $1 \%$ from the inlet to discharge end. The wetland water level was maintained at a constant level of approximately $18 \mathrm{~cm}$. A pproximately 40\% of the wetland was planted with reed (Phragnitessp) and iris (Inssa). For aesthetic purposes, one side of the wetland was nearly completely covered with reed and iris plants while the other side contained few plants. Treated effluent flowed by gravity from the wetland to a valve box that led to a holding tank (1893 L). The holding tank dosed a shallow low-pressure pipe (LPP) drain field ( 5 narrow $0.25 \mathrm{~m}$ gravelless pipe trenches) for final disposal. The advantages of this type of drain field include uniform small doses to the entire adsorption area that in turn promotes unsaturated flow and also results in consistent drying/ reaeration periods between doses (14).

Telemetry Configuration

The wetland system was equipped with telemetry instruments to evaluate the potential to continuously monitor in real-time in-situparameters as a means to monitor treatment effectiveness and maintenance compliance. Parameters monitored with insitu real-time telemetry included pumping duration of the septic tank to the wetland and of the holding tank 
to the drain field (measured using floats located in the pump chambers and a general purpose relay (Allen-Bradley, Milwaukee, WI)), pH of the first compartment of the septic tank (Q25P pH Sensor, Q uantum Analytical Instruments, Collegeville, PA), dissolved oxygen in the valve box at the discharge end of the wetland (Q25D D issolved Oxygen Sensor, Quantum Analytical Instruments, Collegeville, PA), wetland water temperature (O xyguard International, Denmark) and ambient air temperature (Oxyguard International, D enmark) (Figure 1). Telemetry readings were taken in three-minute intervals and transferred using a remote monitoring system (Sensaphone ${ }^{\circledR} 2000$, Sensaphone, Ashton, PA) via a phone line to a computer and stored as text (.txt) files. Telemetry readings recorded June 1, 2004 through August 30, 2004 are included in this paper. Pumping duration of the septic system was used to calculate hydraulic loading rate (HLR) and hydraulic retention time (HRT), while pumping duration of the holding tank was used to calculate soil drain field loading rate. When the pump was activated an electrical signal was sent by the floats via the relay to the Sensaphone ${ }^{\circledR}$ system located in the telemetry panel. HLR was calculated using the following equation: HLR $=\mathrm{O}(\mathrm{PD} * 2.72)$, where $\mathrm{PD}=$ pumping duration $(\mathrm{sec})$ and $2.72=$ pumping rate $\left(\mathrm{L} \mathrm{sec}^{-1}\right)$. HRT was calculated as follows: HRT $=\left(\left(11.89 \mathrm{~m} * 5.49 \mathrm{~m} * 0.23 \mathrm{~m} * 44 * 1000 \mathrm{~L} \mathrm{~m}^{3-1}\right) / \mathrm{HLR}\left(\mathrm{L}_{\text {day }}{ }^{1}\right)\right)$, where $11.89 \mathrm{~m}$ = length of wetland, $5.49 \mathrm{~m}$ = width of wetland, $0.23 \mathrm{~m}=$ depth of water in wetland, and $.44=$ porosity of wetland. Soil drain field loading rate was calculated as LPLR= $\mathrm{O}(\mathrm{PD} * 0.95)$, where $\mathrm{PD}=$ pumping duration (sec) and $0.95=$ pumping rate $\left(\mathrm{L} \mathrm{sec}^{-1}\right)$.

\section{Sampling Methods}

A total of 12 grab water samples were collected between 8 and 12 a.m. during the winter period (January 2004 - March 2004) and a total of 34 water samples were collected at similar times during the summer period (June 2004 - August 2004). Influent samples were taken from the second compartment of the septic tank (primary clarified wastewater) and effluent samples were taken from a $15 \mathrm{~cm}$ diameter PVC temporary monitoring well installed near the discharge point of the wetland. Samples were collected in sterile 1-liter Nalgene® plastic bottles and packed on ice in an insulated cooler during transportation to the laboratory, where they were analyzed within 24 hours. 
Physical and Chemical Analyses

Immediately following sample collection, field measurements of dissolved oxygen, electrical conductivity, pH, and temperature were performed using a YSI Model 556 MPS Meter (Yellow Springs Instruments, Y ellow Springs, $\mathrm{OH}$ ) following standard procedures of the American Public Health Association (2). Upon arrival to the laboratory, samples were refrigerated until processing. Five-day biochemical oxygen demand $\left(\mathrm{BOD}_{5}\right)$ and total suspended solids (TSS) were measured following standard methods (2). Dissolved oxygen values from day five of the $\mathrm{BO}_{5}$ incubation were corrected to adjust for any decreases in oxygen of the dilution water blanks over the five-day incubation period.

\section{Bacteriological Analyses}

Samples were analyzed for fecal coliforms, Escheidia cdi, enterococci, and total heterotrophic bacteria by a modified standard method (2) using a Spiral Biotech Autoplate 4000 Automated Spiral Platter (Spiral Biotech, Inc., Norwood, MA) and the membrane filtration technique (2) using $0.45 \mu \mathrm{m}$ Millipore HA filters (Millipore Corp., Bedford, MA). Serial dilutions were performed or appropriate volumes were filtered to obtain plates with 20-300 colonies (modified standard method) or 20-200 colonies (membrane filtration technique). Plates were incubated for 24 hours at $44.5^{\circ} \mathrm{C}$ on M-FC medium (Difco, D etroit, MI) for fecal coliforms, 24 hours at $44.5^{\circ} \mathrm{C}$ on EC-MUG (D ifco, D etroit, MI) for E. cdi, 48 hours at $35^{\circ} \mathrm{C}$ on $\mathrm{m}$ enterococcus medium (Difco, D etroit, MI) for enterococci, and 48 hours at $35^{\circ} \mathrm{C}$ on R2A medium (Difco, Detroit, MI) for total heterotrophic bacteria.

\section{Statistical Analyses}

All statistical analyses were performed using the SAS Statistical Software Package (SAS Institute Inc., Cary, $\mathrm{NC}$ ). Microbiological data were $\log _{10}$ transformed to obtain geometric means prior to statistical analyses. Differences between physical, chemical, and bacteriological measurements in winter as compared to summer were evaluated using Proc GLM with LSMeans and the tdiff option. Pearson Product Moment Correlation (Pearson's correlation) was used to evaluate correlations between in-situreal-time telemetry measurements and 
physical, chemical, and bacteriological analyses. Unless otherwise noted, significance was based on a $P$ value of less than or equal to 0.05 . 


\section{RE SULTS}

Comparison of Telemetry with Conventional Sampling

Telemetric reports of pumping duration during summer months were used to calculate hydraulic loading rate from the septic tank to the wetland, and to estimate hydraulic retention time within the wetland. The mean hydraulic loading rate to the wetland ranged from 2567 to $2702 \mathrm{~L}_{\text {day }}{ }^{-1}$ depending on the averaging period employed (Table 1). D aily estimates of hydraulic loading rates were quite variable ranging from $356 \mathrm{~L} \mathrm{day}^{-1}$ to $12913 \mathrm{~L}$ day ${ }^{-1}$, and cycled in a regular pattern on a weekly basis (Figure 3,5 ). Highest hydraulic loading rates and lowest hydraulic residence times always were observed on Sundays, consistent with expected peak occupation of the multi-user facility. Average hydraulic retention time ranged from 3.5 to 6.6 days (Table 1) with daily estimates of hydraulic residence time varying from 0.5 to 18.5 days (Figure 3, 5). Estimates of hydraulic loading do not take precipitation into account and assume that all water entering the wetland from the septic tank is dosed to the LPP drain field. Therefore, actual retention time could be either overestimated or underestimated. Discharge rates from the wetland to the drain field also were calculated from telemetric reporting of pumping duration. Average discharge rates ranged from 841 to $1575 \mathrm{~L}_{\text {day }}{ }^{-1}$ (Table 1). Direct comparison of discharge rates with hydraulic loading is complicated by storage of the wastewater in a holding tank prior to dosing of the LPP drain field. Average discharge rates generally were lower than hydraulic loading rates with differences probably reflecting evaporation or evapotranspiration. Water temperatures within the wetland were 21.2 to 23.6 C, compared with air temperatures ranging from 22.1 to $25.3 \mathrm{C}$ (Table 1, Figure 2, 4).

Telemetry values were compared with daily measurements obtained using conventional water analyses over a one-week period, and with samples obtained over the entire summer. Telemetric values for $\mathrm{pH}$ and $\mathrm{D} O$ exhibited some variation over the summer sampling period, with daily averages ranging from 5.8 to 9.3 and $0.25 \mathrm{mg} \mathrm{L}^{-1}$ to $1.48 \mathrm{mg} \mathrm{L}^{-1}$, respectively (Table 1, Figure 2). Telemetric measurements of $\mathrm{pH}$ and $\mathrm{DO}$ were consistently lower than values obtained by conventional analyses performed daily for one week (Table 2) and for the summer period (Table 3, Table 2). Conventional pH measurements exhibited an average for one week 
of 7.45 and a summer average of 7.15 (Table 3). Differences between telemetric and conventional measurements of $\mathrm{pH}$ most probably reflect sampling location in the septic tank (first compared with second settling compartment, respectively). However, differences in measured D O cannot be explained in this manner since conventional field analyses, which exhibited a one week average of $2.45 \mathrm{mg} \mathrm{L}^{-1}$ (Table 2) and a summer average of $1.63 \mathrm{mg} \mathrm{L}^{-1}$ (Table 3), were performed in a sampling well immediately adjacent to the one housing the permanently installed telemetric oxygen probe. Periodic biofouling of the membrane and localized oxygen depletion caused by the probe electrode during intermittent low water flow are likely explanations for the lower average DO values obtained with the telemetric probe.

During the week-long sampling period a significant reduction between influent and effluent $\mathrm{BO} \mathrm{D}_{5}(92.9 \%)$ and TSS (77.2\%) was observed (Table 2). The range of daily BOD $\mathrm{D}_{5}$ in the influent was $157.3 \mathrm{mg} \mathrm{L}^{-1}$ to $207.8 \mathrm{mg} \mathrm{L}^{-1}$ and in the effluent was $2.9 \mathrm{mg} \mathrm{L}^{-1}$ to $26.8 \mathrm{mg} \mathrm{L}^{-1}$ (Figure 7). The range of daily TSS in the influent was $20.0 \mathrm{mg} \mathrm{L}^{-1}$ to $43.3 \mathrm{mg} \mathrm{L}^{-1}$ and in the effluent was $4.4 \mathrm{mg} \mathrm{L}^{-1}$ to $14.4 \mathrm{mg} \mathrm{L}^{-1}$ (Figure 7). Effluent BOD ${ }_{5}$ was highest on Sunday and Monday, which coincided with the highest spike in hydraulic loading rate and lowest hydraulic retention time (Figure 6). Effluent TSS peaked on Sunday, and again on Wednesday reflecting a second smaller peak in hydraulic loading (Figure 6, 7). Values for other measured parameters such as pH, D O and microbial counts were relatively consistent regardless of sampling day, and appeared to be only moderately affected by the observed variations in hydraulic load. Conductivity was significantly reduced by $48 \%$ (Table 2), but exhibited no obvious temporal trend with respect to hydraulic loading. Microbial populations also were consistently and significantly reduced (range 2.0 to $3.2 \log _{10}$ reduction) during passage through the wetland irrespective of sampling day (Table 2).

\section{Seasonal Performance of the Wetland Treatment System}

Conventional analyses of physical and chemical parameters measured in water samples generally indicated that wetland treatment of wastewater was improved in summer compared with winter months (Table 3). The temperature of the influent wastewater differed, averaging 8.9 and $19.4{ }^{\circ} \mathrm{C}$ in winter and summer, respectively. D uring passage through the wetland, wastewater cooled to an average $5.7^{\circ} \mathrm{C}$ during winter months and heated to an average 22.1 
${ }^{\circ} \mathrm{C}$ in summer. $\mathrm{O}$ ther seasonal differences in influent wastewater included higher average $\mathrm{pH}$ and D O ; and lower average conductivity, $\mathrm{BOD}_{5}$ and TSS in winter months compared with summer (Table 3). Wetland treatment resulted in significantly decreased $\mathrm{pH}$ and increased DO during winter, but not summer. Reduction in average $\mathrm{BO}_{5}$ was observed both in winter (64.7\%) and summer (89.5\%), however only the summer reduction was statistically significant due to the variability of winter $\mathrm{BOD}_{5}$ measurement. Significant reductions were observed for TSS (62.9 and 82.9\%) during winter and summer, respectively.

Fecal coliforms, E. cdi, enterococci, and total heterotrophic bacteria also were enumerated during the seasonal sampling regime (Table 4). No differences between numbers in winter and summer influent were observed, with the exception of enterococci, which were significantly greater in winter samples. Significant differences between influent and effluent enumerations, with $\log _{10}$ reductions ranging from 1.6 to 3.5, were observed for all bacterial types regardless of season. Greater reductions were observed in summer compared with winter months for all indicator organisms, but not total heterotrophic bacteria. 


\section{DISCUSSION}

Many communities have constructed centralized systems due to the perception that on-site or decentralized systems are not as advanced technologically, and inferior from a public health and environmental perspective (28). Purchase and management of centralized systems are significantly more expensive than on-site wastewater treatment systems or several individual systems (28). Additionally, low population densities and limited financial resources of rural areas often limit the cost-effective installation of centralized systems. Compared to centralized systems, alternative on-site treatment systems offer great promise for practical and costeffective wastewater remediation, but also great challenges with respect to regulatory compliance. Nationwide, a significant number of on-site systems have been inadequately designed and/ or poorly maintained leading to non-compliance with existing health and environmental regulations $(25,28)$.

The decentralized nature of multiple on-site treatment systems makes conventional water sampling an impractical routine method for community sanitarians to assess ongoing compliance with discharge standards. Telemetric reporting of key performance parameters or alarm situations to a centralized location may eventually offer a more practical way to monitor diverse multiple systems. Currently, few existing on-site systems have been equipped with telemetry equipment. However demonstration projects initiated to investigate the feasibility of telemetry have shown promise (14). Investigation of such experimental systems eventually may lead to an improved understanding of the long-term reliability and function of a variety of innovative, alternative on-site treatment technologies. Q uestions still to be answered include cost and long-term reliability of telemetry devices installed in independent treatment systems, maintenance requirements and longevity of specific sensing devices, and correlation of telemetric measurement of parameters with conventional indicators for monitoring system performance.

D uring the current study telemetry was used to report flow, $\mathrm{pH}, \mathrm{D} 0$, and temperature in an on-site treatment wetland for a three month summer period. Telemetry was found to be most 
useful in describing the dynamic hydraulic loading of the treatment system. Consistent with the known occupancy of the multi-user facility, the single day (Sunday) maximum hydraulic load as well as the smaller peak load occurring regularly at mid-week were clearly identified and quantified. These data confirmed Monday mornings as the optimum sampling time to obtain water samples for conventional analyses. Examination of estimated detention times ( 0.5 to 18.5 days) and dosing volume of the LPP drain field suggest appropriate sizing of the wetland for its intended use. The system is currently in its fourth year of operation and continues to provide effective treatment with no imminent signs of malfunction. Possible statistical correlations between hydraulic loading and parameters such as $\mathrm{BOD}_{5}$, TSS, and indicator organism enumerations/ reductions were examined but significant correlations were not evident.

Monitoring of $\mathrm{pH}$ in the septic tank may be useful in tracking insults and/ or upsets in the system. Telemetry readings indicated the $\mathrm{pH}$ of the first compartment of the system varied ranged from 5.77 to 9.28 during the summer period. High $\mathrm{pH}$ values were recorded during a three-week period at the beginning of summer, the remainder of the values ranged from 5 to 7 . Heavy chemical input from cleaning products that contain bases can cause fluctuations in the $\mathrm{pH}$ of the system. It is possible that the system was disrupted early in the summer do to this sort of activity.

Typically, subsurface flow wetlands are predominately covered by macrophytes and oxygen release from their root system to the rhizosphere has been documented $(3,7,8)$. Monitoring of dissolved oxygen within the wetland system may provide a better understanding the role of plants in these systems. In subsurface flow wetlands, limited contact between the wastewater and the atmosphere and increased biochemical oxygen demand often result in microaerophilic conditions in the system. Bulk oxygenation of the water column is usually ineffective, but localized oxidized environments on or near root surfaces can support growth of aerobic microbes that are thought to promote many treatment processes (9). The wetland in the present study was limited to $40 \%$ plant cover, which was concentrated on a single side for aesthetic purposes. Although aeration of wastewater was observed, an increased and uniform plant cover may further improve aeration and result in improved treatment. 
Examination revealed significant reductions in TSS, total heterotrophic bacteria, fecal coliforms, enterococci, and E. cdi during both seasons although reduced efficacy was noticed in winter. Improved treatment by constructed wetlands during summer months compared to winter is not an uncommon phenomenon. Axler et al. (4) reported reduced efficiency of $\mathrm{BO} \mathrm{D}_{5}$ and TSS removal during winter compared to summer in constructed wetlands. Pundsack et al. (22) observed enhanced short-term seasonal removal of Salmondla and fecal coliforms in experimental wetlands. D ahab and Surampalli (10), in a study of a constructed wetland, reported a decline in reductions in nutrients and fecal coliforms during winter.

Telemetric monitoring of the temperature may prove to be advantageous in predicting treatment efficacy. Such changes can affect overall efficiency, however, simple correlations between temperature and treatment may not be immediately evident $(17,19)$. O verall the treatment wetland proved to be more effective at reducing standard wastewater parameters and indicator organisms in summer as compared to winter probably as a result of decreased temperature. Telemetric readings used in correlation analysis were recorded during summer months when water and air temperature fluctuations were minimal $\left(18.6\right.$ to $25.5^{\circ} \mathrm{C}$ and 15.1 to $25.7^{\circ} \mathrm{C}$, respectively). Telemetric water temperature readings correlated with effluent concentration of fecal coliforms and E. cdi $(r=0.671,0.643)$ and with $\mathrm{BO} \mathrm{D}_{5}$ reduction $(\mathrm{r}=-$ 0.723). Air temperature correlated with TSS reduction $(\mathrm{r}=-0.723)$. Recording continues to date and further review of data collected in the upcoming winter will be used to further investigate these correlations.

A unique aspect of the wetland was the high level of treatment that has been maintained for approximately four or five years of operation. Generally, information on longevity of treatment is absent for on-site wastewater treatment systems. The system achieved significant $\log _{10}$ reductions (1.6 to 3.5) for fecal coliforms, enterococci, E. cdi, and total heterotrophs regardless of season and despite fluctuations in hydraulic loading rate and hydraulic residence time. Reductions in $\mathrm{BOD}_{5}$ and TSS have been reported that are similar to those seen in this research (64.7 and $89.5 \%$ ) and (62.9 and $82.9 \%$ ) for winter as compared to summer. Neralla et al. (20) reported an $80-90 \%$ reduction in $\mathrm{BO} \mathrm{D}_{5}, 81 \%$ reduction in TSS, and $80-90 \%$ reduction in fecal coliforms in a study of eight household constructed wetlands treating 
household wastewater. Ottova et al. (21) reported removal rates of 95.3 to $99.9 \%$ for fecal coliforms and enterococci removal of 93.2 to $99.5 \%$ in five constructed wetland systems. Barrett et al. (5) reported variable log reductions ranging between 0.5 to 4.2 for fecal coliforms and 0.1 to 2.4 for enterococci for several subsurface flow wetlands. Hench et al. (16) reported removal rates in vegetated mesocosms of $42 \%$ for $\mathrm{BOD}_{5}, 83 \%$ for TSS, and $>99 \%$ removal of fecal coliforms and enterococci, although removal of $\mathrm{BOD}_{5}$ and TSS in this study were significantly reduced during second year of experiment. 


\section{CONCLUSIONS}

Real-time monitoring of the constructed wetland proved to be most useful in providing information regarding changes in hydraulic loading rate and retention time of the system. Initial correlations between telemetric recordings and conventional analyses were limited. A longer sampling period with concurrent telemetry is necessary to vigorously investigate possible correlations. Use of telemetry and sampling of the system continues to date and will be further evaluated. $\mathrm{O}$ verall the system was able to reduce $\mathrm{BOD}_{5}$ and significantly reduce TSS, indicator organisms, and total heterotrophs regardless of fluctuations in hydraulic loading rate, retention time, and season. Slight reduction of system efficiency was noticed during winter months, but the wetland appears to meeting most WVDEP regulations. $\mathrm{BOD}_{5}$ sometimes exceeded the $30 \mathrm{mg} \mathrm{L}^{-1}$ required for direct discharge to a receiving stream, particularly during winter months. However, the wetland discharges to a LPP soil drain field that imparts further treatment. Overall the wetland system appears to function as designed providing reliable and cost-effective on-site wastewater treatment. 
Table 1. Telemetric measurement of wetland parameters averaged over differing sampling periods during summer months*

\begin{tabular}{llll}
\hline & & & \\
Parameter & Summer & August & 7-Day \\
\hline Hydraulic Loading Rate $\left(\mathrm{L} \mathrm{day}^{-1}\right)$ & $2567(350)$ & $2575(580)$ & $2702(787)$ \\
Soil Drainfield Loading Rate $\left(\mathrm{L} \mathrm{day}^{-1}\right)$ & $1284(222)$ & $1575(517)$ & $841(348)$ \\
Hydraulic Residence Time (days) & $6.6(5.9)$ & $5.9(1.1)$ & $3.5(0.7)$ \\
Wetland Temp $\left({ }^{\circ} \mathrm{C}\right)$ & $22.5(0.2)$ & $21.6(0.2)$ & $22.5(0.3)$ \\
Air Temp $\left({ }^{\circ} \mathrm{C}\right)$ & $21.5(0.3)$ & $21.2(0.5)$ & $23.8(0.5)$ \\
DO $\left(\mathrm{mg} \mathrm{L}^{-1}\right)$ & $0.94(0.03)$ & $0.77(0.05)$ & $1.04(0.10)$ \\
pH & $6.80(0.09)$ & $6.65(0.03)$ & $6.71(0.04)$ \\
\hline
\end{tabular}

* Mean (standard error in parentheses) of 93 (summer), 31(August), and 7 (7-day) daily means. 
Table 2. Physical/ chemical parameters and microbial densities of primary clarified wetland influent and wetland effluent over 7-day intensive sampling period*

\begin{tabular}{lllc}
\hline & & & \\
Parameter & Influent & Effluent & Significance \\
\hline $\mathrm{pH}$ & $7.45(0.08)$ & $7.17(0.10)$ & $\mathrm{a}$ \\
Temperature $\left({ }^{\circ} \mathrm{C}\right)$ & $20.3(0.24)$ & $22.7(0.40)$ & $\mathrm{a}$ \\
$\mathrm{DO}\left(\mathrm{mg} \mathrm{L}^{-1}\right)$ & $2.17(0.08)$ & $2.45(0.22)$ & \\
Conductivity $\left(\mathrm{mS} \mathrm{cm}^{-1}\right)$ & $1.69(0.03)$ & $0.81(0.10)$ & $\mathrm{a}$ \\
$\mathrm{BOD}_{5}\left(\mathrm{mg} \mathrm{L}^{-1}\right)$ & $183.4(7.2)$ & $14.8(4.4)$ & $\mathrm{a}$ \\
$\left.\mathrm{TSS}_{(\mathrm{mg} \mathrm{L}}^{-1}\right)$ & $31.9(3.1)$ & $9.2(1.2)$ & $\mathrm{a}$ \\
Fecal coliforms $\left(\log _{10} \mathrm{CFU} 100 \mathrm{~mL}^{-1}\right)$ & $5.1(0.33)$ & $1.9(0.02)$ & $\mathrm{a}$ \\
E. coli $\left(\log _{10} \mathrm{CFU} 100 \mathrm{~mL}^{-1}\right)$ & $4.2(0.41)$ & $1.6(0.00)$ & $\mathrm{a}$ \\
Enterococci $\left(\log _{10} \mathrm{CFU} 100 \mathrm{~mL}^{-1}\right)$ & $5.0(0.17)$ & $2.1(0.09)$ & $\mathrm{a}$ \\
Total heterotrophic bacteria $\left(\log _{10} \mathrm{CFU} \mathrm{mL}\right)$ & $6.8(0.17)$ & $4.8(0.15)$ & $\mathrm{a}$ \\
\hline
\end{tabular}

* Mean (standard error in parentheses) of 7 samples (3 replicates/sample) collected during

${ }^{a}$ Indicates effluent was significantly different than influent $(\mathrm{P}<0.05)$. 
Table 3. Physical and chemical parameters of primary clarified wetland influent and wetland effluent during winter compared to summer*

\begin{tabular}{|c|c|c|c|c|c|}
\hline \multirow[b]{2}{*}{ Parameter } & \multicolumn{2}{|c|}{ Influent } & \multicolumn{2}{|c|}{ Effluent } & \multirow[b]{2}{*}{ Significance } \\
\hline & Winter & Summer & Winter & Summer & \\
\hline $\mathrm{pH}$ & $7.89(0.26)$ & $7.15(0.08)$ & $7.13(0.28)$ & $7.19(0.05)$ & $\mathrm{ac}$ \\
\hline Temperature $\left({ }^{\circ} \mathrm{C}\right)$ & $8.9(0.9)$ & $19.4(0.3)$ & $5.7(1.4)$ & $22.1(0.3)$ & $a b c d$ \\
\hline $\mathrm{DO}\left(\mathrm{mg} \mathrm{L}^{-1}\right)$ & $2.59(0.65)$ & $1.63(0.14)$ & $3.97(0.77)$ & $1.89(0.15)$ & $a b c$ \\
\hline Conductivity $\left(\mathrm{mS} \mathrm{cm}^{-1}\right)$ & $1.38(0.08)$ & $1.64(0.02)$ & $1.21(0.15)$ & $0.83(0.05)$ & $\mathrm{abd}$ \\
\hline $\mathrm{BOD}_{5}\left(\mathrm{mg} \mathrm{L}^{-1}\right)$ & $150.8(32.3)$ & $218.4(16.0)$ & $82.2(15.7)$ & $25.5(5.8)$ & a d \\
\hline $\mathrm{TSS}\left(\mathrm{mg} \mathrm{L}^{-1}\right)$ & $29.8(4.4)$ & $37.5(2.2)$ & $17.6(2.4)$ & $7.8(0.8)$ & $\mathrm{bcd}$ \\
\hline
\end{tabular}

* Mean (standard error in parentheses) of samples (3 replicates/sample) collected during winter (January-March n=6) and summer (June-August $\mathrm{n}=17$ ).

${ }^{a}$ Indicates significant difference between influent winter compared to influent summer $(\mathrm{P}<0.05)$.

${ }^{\mathrm{b}}$ Indicates significant difference between effluent winter compared to effluent summer $(\mathrm{P}<0.05)$.

${ }^{\mathrm{c}}$ Indicates significant difference between influent winter compared to effluent winter $(\mathrm{P}<0.05)$.

${ }^{\mathrm{d}}$ Indicates significant difference between influent summer compared to effluent summer $(\mathrm{P}<0.05)$. 
Table 4. Microbial densities of primary clarified wetland influent and wetland effluent during winter compared to summer*

\begin{tabular}{|c|c|c|c|c|c|}
\hline \multirow[b]{2}{*}{ Microbial population } & \multicolumn{2}{|c|}{ Influent } & \multicolumn{2}{|c|}{ Effluent } & \multirow[b]{2}{*}{ Significance } \\
\hline & Winter & Summer & Winter & Summer & \\
\hline Fecal coliforms $\left(\log _{10}\right.$ CFU $\left.100 \mathrm{~mL}^{-1}\right)$ & $5.5(0.38)$ & $5.6(0.17)$ & $3.3(0.19)$ & $2.1(0.08)$ & $b c d$ \\
\hline E. $\operatorname{coli}\left(\log _{10}\right.$ CFU $\left.100 \mathrm{~mL}^{-1}\right)$ & $5.2(0.21)$ & $4.7(0.22)$ & $3.0(0.18)$ & $2.0(0.09)$ & $\mathrm{bcd}$ \\
\hline Enterococci $\left(\log _{10}\right.$ CFU $\left.100 \mathrm{~mL}^{-1}\right)$ & $5.5(0.37)$ & $4.8(0.17)$ & $3.0(0.40)$ & $2.2(0.07)$ & $a b c d$ \\
\hline Total heterotrophic bacteria $\left(\log _{10} \mathrm{CFU} \mathrm{mL}^{-1}\right)$ & $6.9(0.17)$ & $6.9(0.10)$ & $5.3(0.22)$ & $4.9(0.11)$ & $\mathrm{cd}$ \\
\hline
\end{tabular}

* Geometric mean (standard error in parentheses) of samples (3 replicates/sample) collected during winter (January-March $\mathrm{n}=6$ ) and summer (June-August $\mathrm{n}=17$ ).

${ }^{\text {a }}$ Indicates significant difference between influent winter compared to influent summer.

${ }^{\mathrm{b}}$ Indicates significant difference between effluent winter compared to effluent summer.

${ }^{c}$ Indicates significant difference between influent winter compared to effluent winter.

${ }^{\mathrm{d}}$ Indicates significant difference between influent summer compared to effluent summer. 


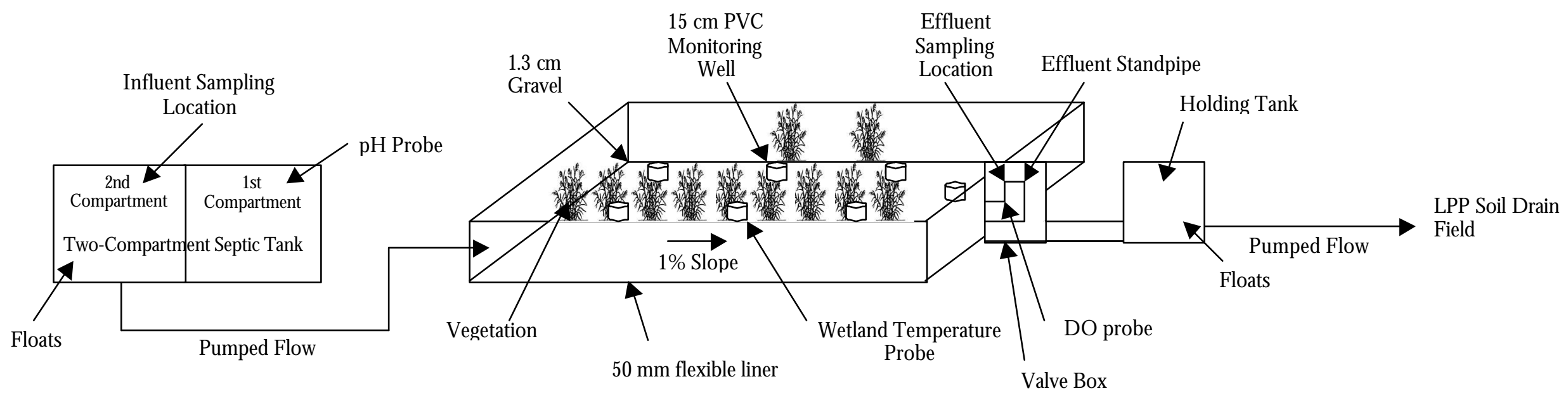

Figure 1. General schematic of the constructed subsurface flow wetland system. 


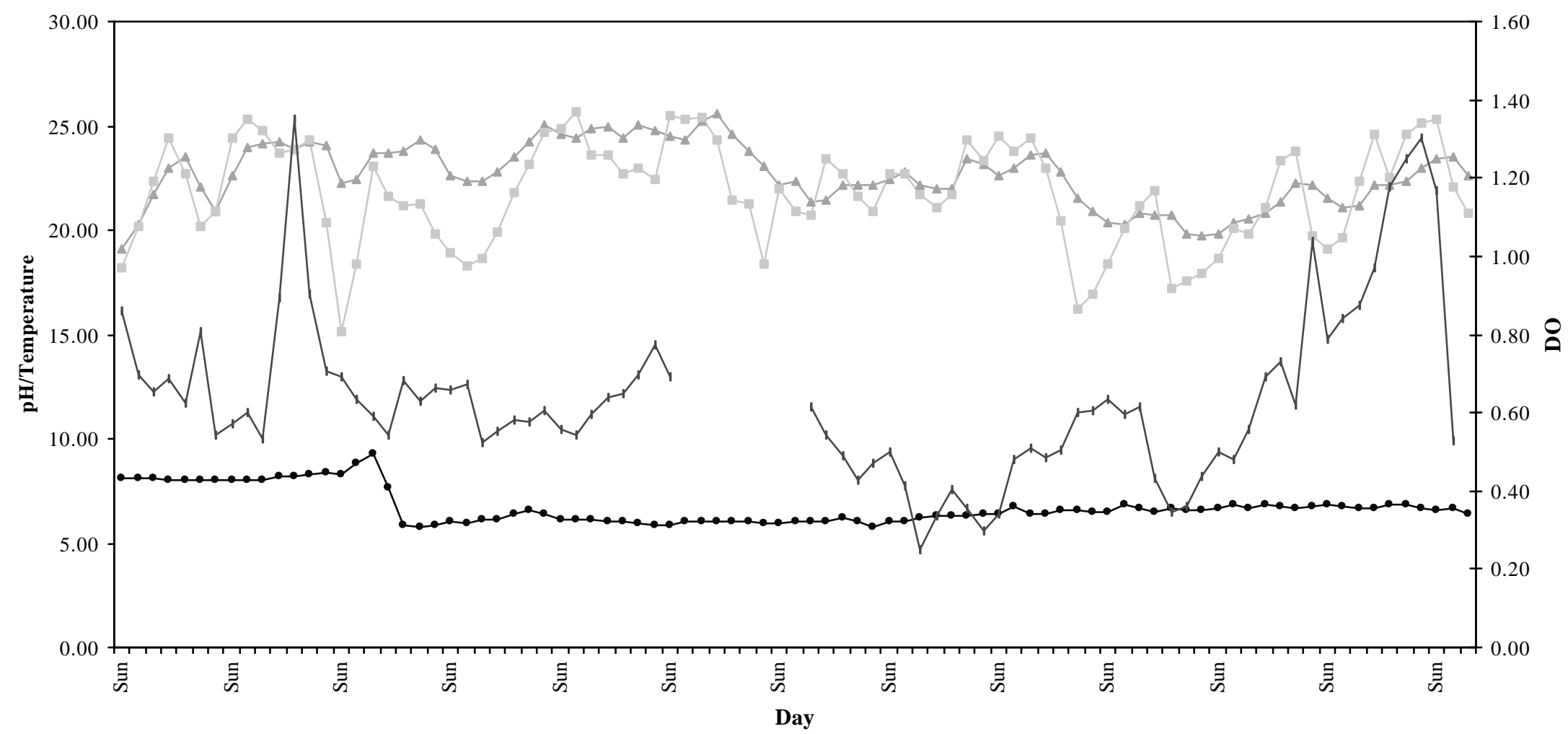

Figure 2. Daily averages for telemetric readings of $\mathrm{pH}$, wetland temperature $\left({ }^{\circ} \mathrm{C}\right)$, air temperature $\left({ }^{\circ} \mathrm{C}\right)$, and $\mathrm{DO}\left(\mathrm{mg} \mathrm{L}^{-1}\right)$ recorded over summer period. Symbols are as follows: ( ) pH; ( ) wetland temperature; ( ) air temperature; ( ) D O. Missing values for D O are due to probe malfunctions. 


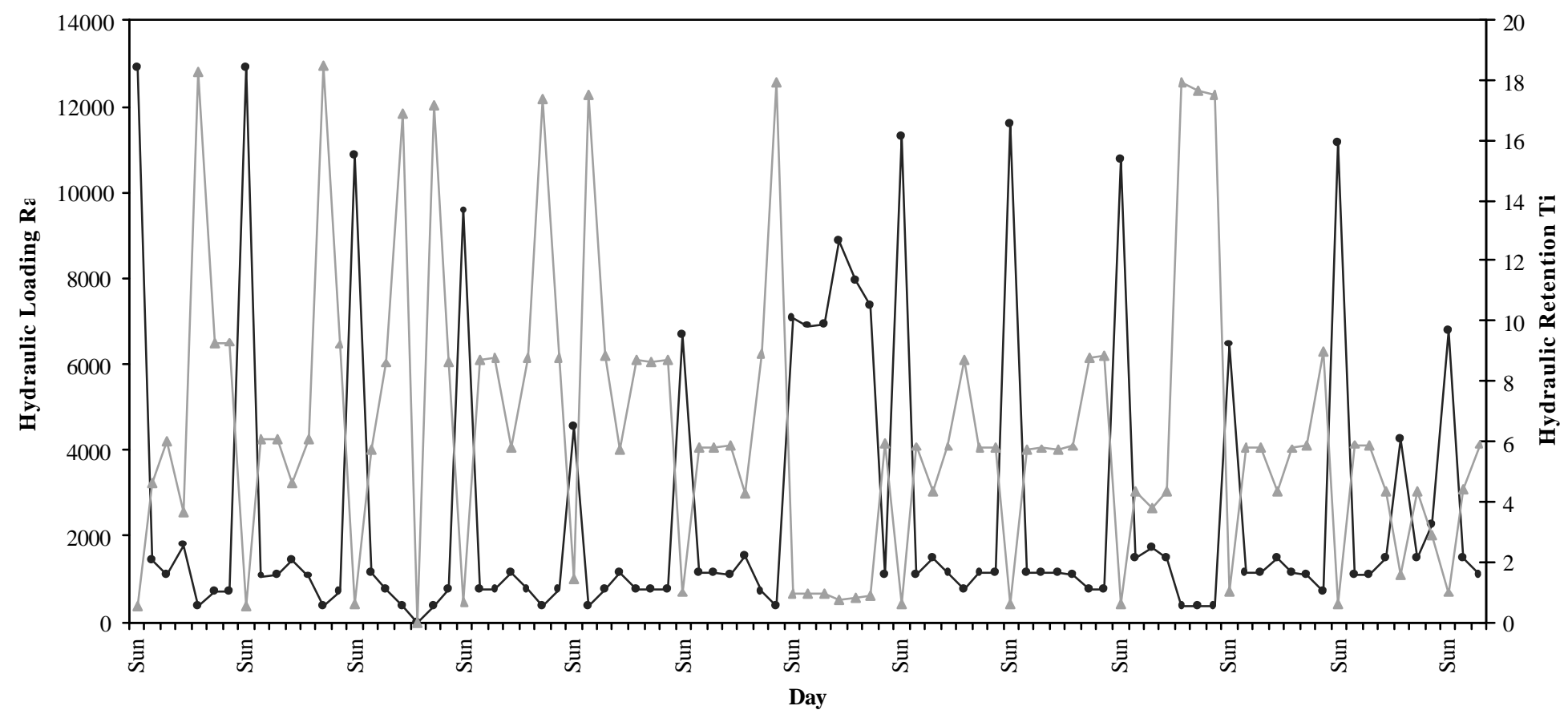

Figure 3. Daily averages for calculated hydraulic loading rate (L day $\left.{ }^{1}\right)$ and hydraulic retention time (day) recorded over summer period. Symbols are as follows: ( ) hydraulic loading rate; ( ) hydraulic retention time. 


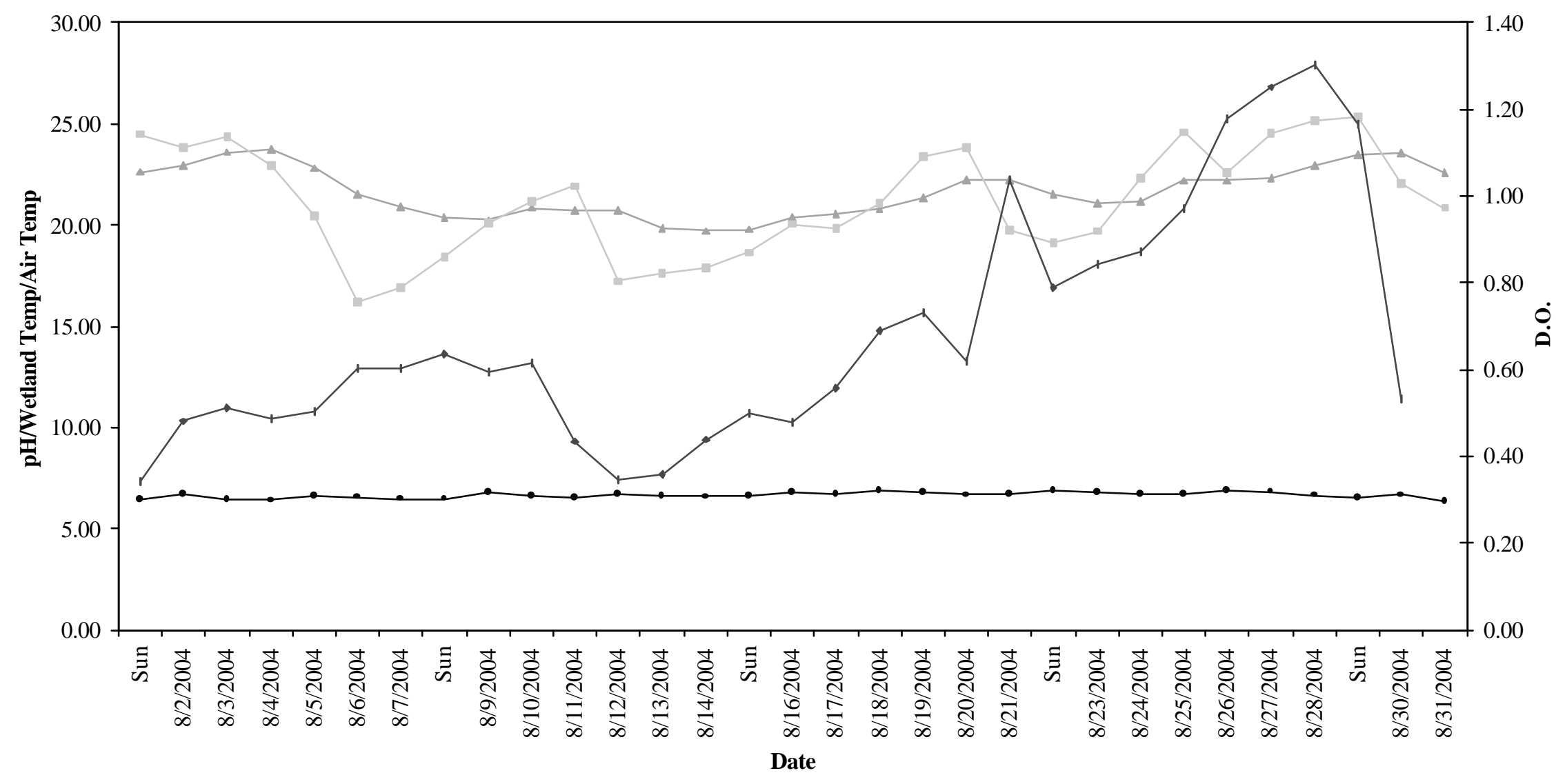

Figure 4. Daily averages for telemetric readings of $\mathrm{pH}$, wetland temperature $\left({ }^{\circ} \mathrm{C}\right)$, air temperature $\left({ }^{\circ} \mathrm{C}\right)$, and DO $\left(\mathrm{mg} \mathrm{L}^{-1}\right)$ recorded during August. Symbols are as follows: ( ) pH; ( ) wetland temperature; ( ) air temperature; ( ) D O. Missing values for D O are due to probe malfunctions. 


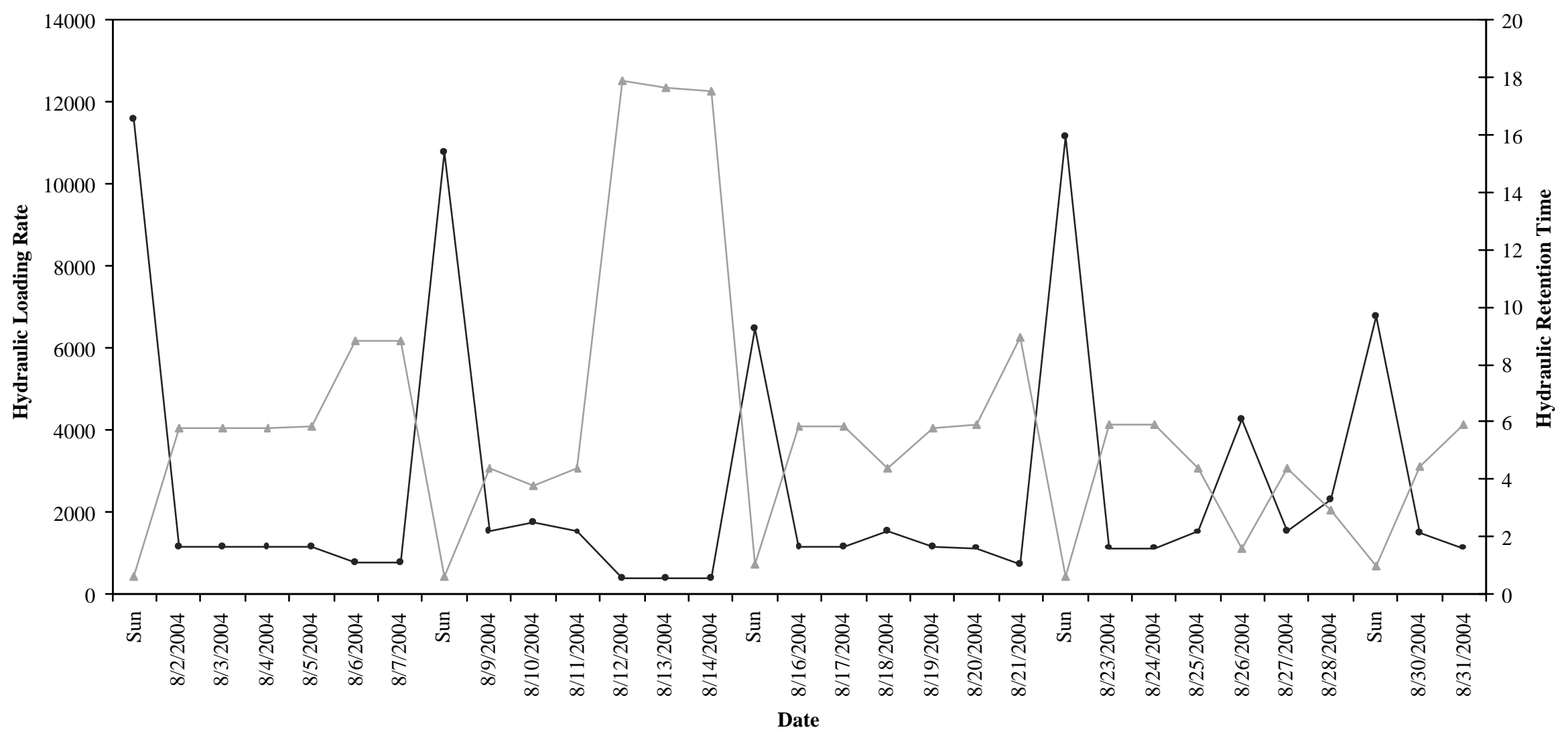

Figure 5. D aily averages for calculated hydraulic loading rate (L day $\left.{ }^{1}\right)$ and hydraulic retention time (day) recorded during August. Symbols are as follows: ( ) hydraulic loading rate; ( ) hydraulic retention time. 


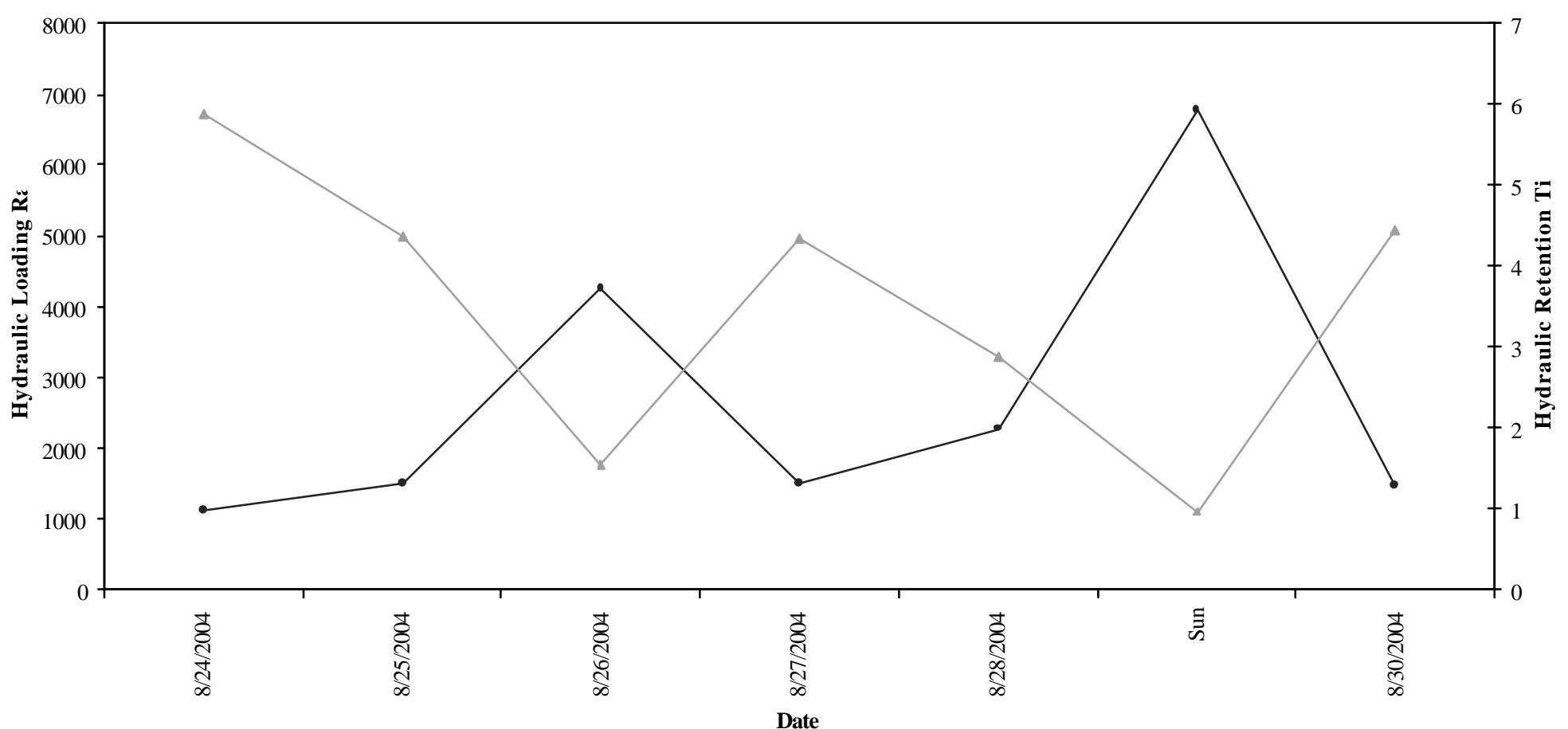

Figure 6. Daily averages for calculated hydraulic loading rate $\left(\mathrm{L} \mathrm{day}^{-1}\right)$ and hydraulic retention time (day) recorded during 7-day sampling. Symbols are as follows: ( ) hydraulic loading rate; ( ) hydraulic retention time. 


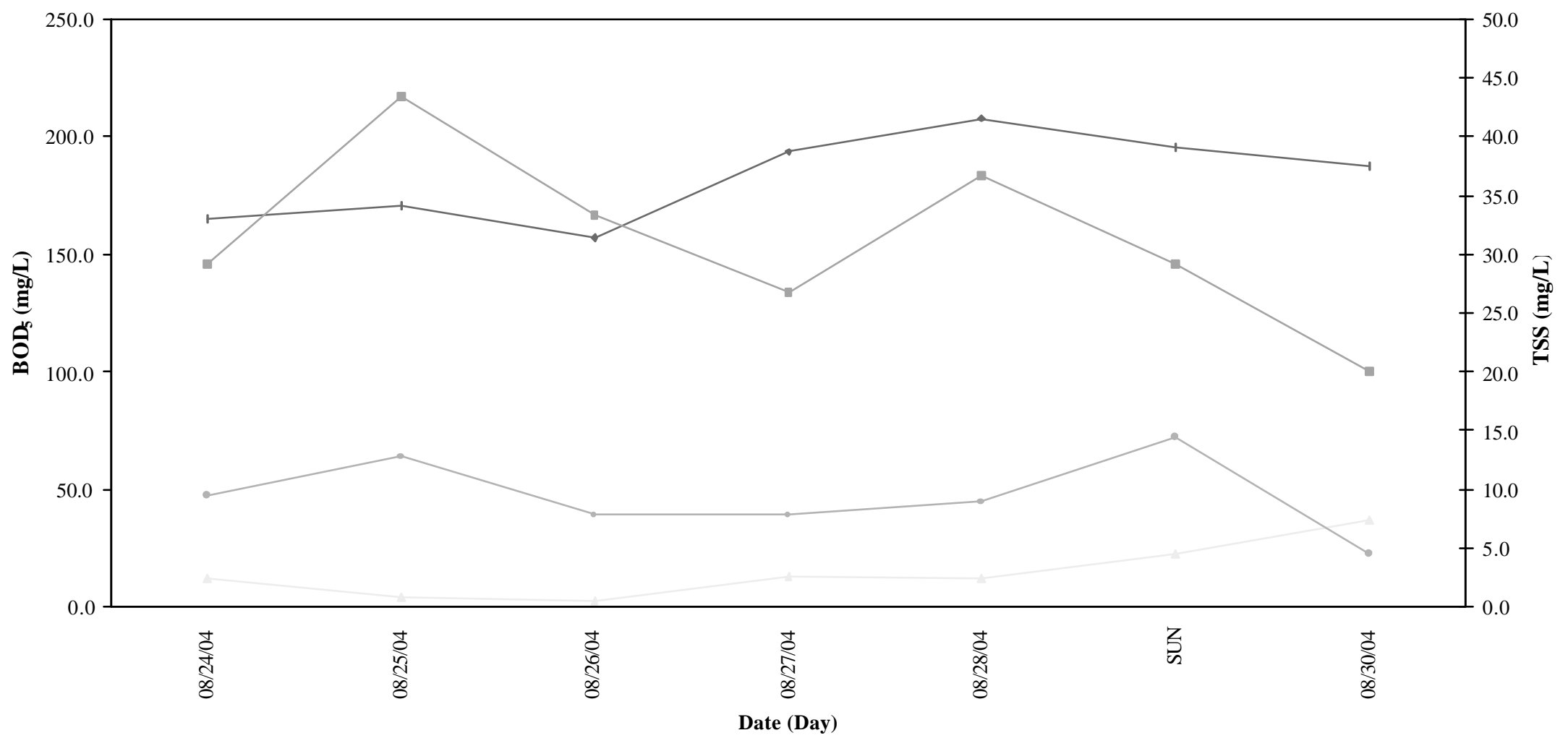

Figure 7. D aily averages for conventional analysis of influent and effluent BOD $5\left(\mathrm{mg} \mathrm{L}^{-1}\right)$ and TSS (mg L-1) measured over 7-day sampling period. Symbols are as follows: ( ) Influent TSS; ( ) Influent BOD 5 ; ( ) Effluent TSS; ( ) Effluent BOD D. $^{\circ}$ 


\section{Reference List}

1 Amann, R., H. Lemmer, and M. Wagner. 1998. Monitoring the community structure of wastewater treatment plants: a comparison of old and new techniques. FEMS Microbiology Ecology 25:205-215.

2 APHA (American Public H ealth Association). Standard Methods for the Examination of Water and Wastewater, 20th ed. American Public Health Association Inc., New York, N.Y.

3 Amstrong, W. 1964. Nature 204:801.

4 Axler, R., J. Henneck, and B. McCarthy. 2001. Residential subsurface flow treatment wetlands in northern Minnesota. Water Science and Technology 44:345-352.

5 Barrett, E. C., M. D. Sobsey, C. H. House, and K. D. White . 2001. Microbial indicator removal in onsite constructed wetlands for wastewater treatment in the southeastern U.S. Water Science and Technology 44:177-182.

6 Bastian, R. K. and D. A. Hammer. 1989. The use of constructed wetlands for wastewater treatment and recycling, p. 59-68. InConstructed Wetlands for Water Quality Treatment. CRC Press, Boca Raton, FL.

7 Brix, H. 1994. Functions of macrophytes in constructed wetlands. Water Science and Technology 29:71-78.

8 Brix, H. 1997. D o macrophytes play a role in constructed treatment wetlands? Water Science and Technology 35:11-17.

9 Coleman, J., K. H ench, K. Garbutt, A. Sexstone, G. Bissonnette, and J. Skousen. 2001. Treatment of domestic wastewater by three plant species in constructed wetlands. Water, Air, and Soil Pollution 128:283-295.

10 Dahab, M. F. and R. Y. Surampalli. 2001. Subsurface-flow constructed wetlands treatment in the plains: five years of experience. Water Science and Technology 44:375380.

11 Dahab, M. F., R. Y. Surampalli, and W. Liu. 2001. Performance modeling of subsurface-flow constructed wetland systems. Water Science and Technology 44:231235.

12 Decamp, 0. and A. Warren. 2001. Abundance, biomass, and viability of bacteria in wastewaters: impact of treatment in horizontal subsurface flow constructed wetlands. Water Research 35:3496-3501.

13 Dufour, A. P. 1977. Escheidhia cdi: the fecal coliform, p. 48-58. InBacterial 
Indicators/ Health Hazards Associated with Water. ASTM STP 635. American Society for Testing and Materials, Philadelphia, PA.

14 Ebeling, J., S. T sukuda, J. Hankins, and C. Solomon. Washington D C, USA. Evaluation and real-time monitoring of a recirculating sand and peat filter. Third NSF International Symposium of Small D rinking Water and Wastewater Systems.

15 Geldreich, E. E. 1978. Bacterial pollution and indicator concepts in feces, sewage, stormwater, and solid wastes, p. 51-97. InIndicators of viruses in water and food. Ann Arbor Science, Ann Arbor, MI.

16 Hench, K. R., G. K. Bissonnette, A. J. Sexstone, J. G. Coleman, K. Garbutt, and J. G. Skousen. 2003. Fate of physical, chemical, and microbial contaminants in domestic wastewater following treatment by small constructed wetlands. Water Research 37:921927.

17 Kadlec, R. H. 1999. Chemical, physical, and biological cycles in treatment wetlands. Water Science and Technology 40:37-43.

18 Kadlec, R. H. and R. L. Knight. 1996. Treatment Wetlands, InLewis Publishers, CRC, New York, NY.

19 Manios, T., P. Millner, and E. Stentiford. 2000. Effect of rain and temperature on the performance of constructed reed beds. Water Environment Research 72:305-312.

20 N eralla, S., R. W. Weaver, B. J. Lesikar, and R. A. Persyn. 2000. Improvement of domestic wastewater quality by subsurface flow constructed wetlands. Bioresource Technology 75:19-25.

21 Ottova, V., J. Balcarova, and J. Vymazal 1997. Microbial characteristics of constructed wetlands. Water Science and Technology 35:117-123.

22 Pundsack, J., R. Axler, and R. Hicks. 2001. Seasonal pathogen removal by alternative on-site wastewater treatment systems. Water Environment Research 73:204-212.

23 Reed, S., R. Crites, and J. Middlebrooks. 1995. Natural systems for waste management, Seventh Edition. McG raw-Hill Inc., New Y ork, NY.

24 Richardson, K. J., M. H. Stewart, and R. L. Wolfe. 1991. Application of gene probe technology to the water industry. Journal American Water Works Association. 83:71-81.

25 Sexstone, A., M. Aiton, G. Bissonnette, K. Fleming, K. Kinneer, K. Hench, T. Bozicevich, B. Cooley, and E. Winant 2000. A survey of home aerobic treatment systems operating in six West Virginia counties. Small Flows Quarterly 1:38-46.

26 Stiles, N . 2002. Flushing out the straight pipes. Small Flows Q uarterly 3:18-21. 
27 U.S. Environmental Protection Agency. 1993. Subsurface flow constructed wetlands for wastewater treatment: a technology assessment. O ffice of Water, USEPA, Washington, DC.

28 U.S. Environmental Protection Agency. 2002. USEPA Onsite wastewater treatment systems manual. USEPA, Washington, D C.

29 Yakub, G. P., D. A. Castric, K. L. Stadteman-Knauer, M. J. Tobin, M. Blazina, T. N. H eineman, G. Y. Yee, and L. Frazier. 2002. Evaluation of colilert and enterolert defined substrate methodology for wastewater applications. Water Environment Research 74:131-135. 


\section{CHAPTER 2: BACTERIAL DIVERSITY WITHIN A CONSTRUCTED WETLAND TREATING WASTEWATER: A CASE STUDY}

\section{INTRO D UCTION}

D ecentralized on-site wastewater treatment systems serve approximately 25\% of the U.S. population (40). Individual households most commonly employ a septic tank with a soil drain field, however effective treatment sometimes is not achieved due to poor site conditions such as steep topography, low soil percolation, and limited availability of land. Septic tank effluents frequently are reported as significant sources of groundwater contamination by pathogenic bacteria and viruses (40). Constructed subsurface flow wetlands are now in use both as supplements to and replacements for soil drain fields in on-site wastewater treatment. Primary clarified wastewater effluent enters the wetland and flows horizontally below the surface of the substrate (usually gravel planted with aquatic macrophytes) prior to discharge. The water level within the wetland is maintained constant by an outflow standpipe at the discharge end of the wetland. Subsurface flow wetlands result in decreased mosquito breeding, objectionable odors, and the possibility of human/ animal contact with partially treated wastewater. Previous studies have reported acceptable wastewater treatment by subsurface flow wetlands, although seasonal variability and longevity of treatment effectiveness remain a question $(4,10,25,31,39)$.

Physical, chemical, and microbiological processes in subsurface wetlands reduce total suspended solids (TSS), biochemical oxygen demand $\left(\mathrm{BOD}_{5}\right)$, as well as the number of pathogenic microorganisms in wastewater (3). Heterotrophic bacteria are thought to play a central role in the wastewater treatment process within constructed subsurface flow wetlands. They dominate both in numbers and biomass, and regulate mineralization and immobilization of organic and inorganic nutrients (1). However, the physiology, survival strategies, and community structure of heterotrophic bacterial populations in constructed subsurface flow wetland systems have not been extensively studied. Relatively little is known about how changes in diversity of the heterotrophic microbial community might affect treatment of 
wastewater in these small-scale subsurface flow treatment systems. Heterotrophic bacteria vary in cell size and can be selectively partitioned by membrane filtration. Studies of small or dwarf cells have been conducted in marine environments (19), groundwater (26,37), and soil $(12,35)$. Studies of the small cell fraction of heterotrophic communities have not yet been performed in wastewater wetlands. A better understanding of all fractions of the bacterial community and their dynamics in these systems may eventually contribute to improved system design, functioning, and efficiency of constructed subsurface flow wetland systems.

In a previous study by Hench et al. (20), changes in functional diversity of wetland heterotrophic bacteria were observed by season and due to the presence or absence of plants. The authors noted failing treatment effectiveness in the experimental wetland system examined and suggested that more detailed studies were called for in robust, well-functioning wetlands. In the present study, heterotrophic bacterial diversity was evaluated in a wellestablished constructed wetland providing wastewater treatment for a large multi-user facility. Treatment effectiveness and compliance was determined through evaluations of $\mathrm{BOD}_{5}, \mathrm{TSS}$, and enumeration of indicator microbial populations. Community-level physiological profiles (CLPP) of the total cell (TC), large cell (LC), and small cell (SC) fractions of the heterotrophic bacteria community were determined using BIOLO G ${ }^{\circledR}$ ECO plates. In addition, bacterial community diversity was determined using $16 \mathrm{~S}$ rRNA genes amplified by polymerase chain reaction (PCR) and separated by denaturing gradient gel electrophoresis (DGGE). The objectives were to determine whether passage of primary clarified wastewater through the constructed wetland system resulted in significant reductions of the physical and chemical parameters, fecal indicator bacteria, and total heterotrophic bacteria; and whether the functional and/ or genetic diversity of the LC, TC, and SC fractions of the bacterial community varied due to treatment by the wetland system. 


\section{METHODS}

Wetland System

The system investigated was a constructed subsurface flow gravel wetland $(\sim 11.89 \mathrm{~m} \times 5.49 \mathrm{~m}$ $\mathrm{x} 0.45 \mathrm{~m}$ ) treating primary clarified wastewater from a two-compartment septic tank (Tank 1 $5678 \mathrm{~L}$ and Tank $21893 \mathrm{~L}$ ) discharging from a multi-user facility (Figure 1). The second compartment of the septic tank acted as a dosing tank for the wetland. The number of users attending the facility varied throughout the week and also throughout the study period; however, the maximum number of users was always on Sunday. It was estimated approximately 1300 people were present on Sundays, with numbers during the remainder of the week ranging from 10-250 depending on on-going programs and functions. The wetland was constructed with $1.3 \mathrm{~cm}$ gravel (approximately $44 \%$ porosity - based on field testing), lined with a $50 \mathrm{~mm}$ flexible liner, and the area surrounding the wetland was constructed with larger stone to limit overland runoff to the wetland. The slope of the wetland was approximately $1 \%$ from the inlet to discharge end. The wetland water level was maintained at a constant level of approximately $18 \mathrm{~cm}$. A pproximately 40\% of the wetland was planted with reed (Phragnitessp) and iris (Inssp). For aesthetic purposes, one side of the wetland was nearly completely covered with reed and iris plants while the other side contained few plants. Treated effluent flowed by gravity from the wetland to a valve box that led to a holding tank (1893 L). The holding tank dosed a shallow low-pressure pipe (LPP) drain field ( 5 narrow $0.25 \mathrm{~m}$ gravelless pipe trenches) for final disposal. The advantages of this type of drain field include uniform small doses to the entire adsorption area that in turn promotes unsaturated flow and also results in consistent drying/ reaeration periods between doses (14). Telemetry was used to report pumping duration from the septic tank to the wetland system. From this data, the average summer hydraulic loading rate from the septic tank to the wetland was calculated to be $2567 \mathrm{~L}$ day $^{-1}$ and the estimated hydraulic retention time within the wetland was 6.6 days. Field porosity of the system was determined to be $44 \%$. 
Sampling Methods

A total of 46 grab water samples were collected between 8 and 12 A.M. during January 2004 August 2004. Influent samples were taken from the second compartment of the septic tank (primary clarified wastewater) and effluent samples were taken from a $15 \mathrm{~cm}$ diameter PVC temporary monitoring well installed near the discharge point of the wetland. A total of six intermediate grab samples were collected from six $15 \mathrm{~cm}$ diameter PVC temporary monitoring wells installed over the distance of the wetland (Figure 1). Samples were collected in sterile 1liter Nalgene plastic bottles and packed on ice in an insulated cooler during transportation to the laboratory, where they were analyzed within 24 hours.

Physical/ Chemical Analyses

Immediately following sample collection, field measurements of dissolved oxygen, electrical conductivity, $\mathrm{pH}$, and temperature were performed using a Y SI Model 556 MPS Meter (Yellow Springs Instruments, Yellow Springs, $\mathrm{OH}$ ) following standard procedures of the American Public Health Association (2). Upon arrival to the laboratory, samples were refrigerated until processing. At the time of processing, samples were allowed to warm to room temperature prior to analyses. Five-day biochemical oxygen demand ( $\mathrm{BO}_{5}$ ) and total suspended solids (TSS) were measured following standard methods (2). Dissolved oxygen values from day five of the BO D5 incubation were corrected to adjust for any decreases in oxygen of the dilution water blanks over the five-day incubation period.

\section{Bacteriological Analyses}

Samples were analyzed for fecal coliforms, Escheidia cdi, enterococci, and total heterotrophic bacteria by a modified standard method using a Spiral Biotech Autoplate 4000 Automated Spiral Plater (Spiral Biotech, Inc., Norwood, MA) and the standard method membrane filtration technique using 0.45 im Millipore HA filters (Millipore Corp., Bedford, MA) (2). Serial dilutions were performed or appropriate volumes were filtered to obtain plates with 20300 colonies (modified standard method) or 20-200 colonies (membrane filtration technique). Plates were incubated for 24 hours at $44.5^{\circ} \mathrm{C}$ on $\mathrm{M}$-FC medium (D ifco, D etroit, MI) for fecal 
coliforms, 24 hours at $44.5^{\circ} \mathrm{C}$ on EC-MUG for E. cdi (Difco, D etroit, MI), 48 hours at $35^{\circ} \mathrm{C}$ on m-Enterococcus medium for enterococci (D ifco, D etroit, MI), and 48 hours at $35^{\circ} \mathrm{C}$ on R2A (D ifco, D etroit, MI) medium for total heterotrophic bacteria.

Sample Preparation for Culture-D ependent and Culture-Independent Analyses Bacterial cells from one influent and effluent sample were sequentially collected on $0.45 \mu \mathrm{m}$ (large cells, LC) and $0.22 \mu \mathrm{m}$ (small cells, SC) Millipore HA filters (3 filters/ sample) (Millipore Corp.). Culture-independent cells (CI) were collected by placing filters into test tubes containing $15 \mathrm{ml}$ of sterile saline solution $(0.85 \% \mathrm{NaCl})$ and vigorously vortexing for $1-2 \mathrm{~min}$. Culture-dependent cells (CD) were obtained by first placing filters (3 filters/ sample) on R2A medium (D ifco) and incubating for 48 hours at $35^{\circ} \mathrm{C}$ prior to cell collection.

Inoculation and Reading of BIOLOG Plates

An aliquot (9.6 ml), of the CD SC and LC cell suspensions described above, was used to inoculate BIOLOG $₫$ ECO plates ( $100 \mathrm{ul} /$ well, 3 replicates per plate, $n=3$ ). Culturedependent cell suspensions were serially diluted ( $10^{2}$ final dilution). For total cells (TC) CI an aliquot (9.6 ml) of undiluted wastewater was used to inoculate BIOLOG ${ }^{\circledR}$ ECO plates. BIO LOG ${ }^{\circledR}$ plates were incubated in the dark at $25^{\circ} \mathrm{C}$. Plates were read 8 times over approximately 100 hours using a SpectraMAX 340PC plate reader (Molecular Devices Corporation, Sunnyvale, CA) equipped with a $595 \mathrm{~nm}$ filter.

Denaturing G radient G el Electrophoresis (D G GE)

DNA was extracted from $1.8 \mathrm{ml}$ aliquots of cell suspensions using MoBio Microbial DNA extraction kits (MoBio Laboratories, Carlsbad, CA). The variable V3 region of the $16 \mathrm{~S}$ rRNA gene from members of the domain Eubateia was PCR amplified by using PRBA338F (5'ACTCCTACG GGAG GCAGCAG -3') with a GC clamp and PRUN518R (5'ATTACCGCG GCTGCTG G -3') primers in a Px2 Thermal Cycler (Thermo Electron Co., Needham Heights, MA). Fifty $\mu \mathrm{l}$ PCR reaction mixtures contained 1× PCR buffer (Promega, Madison, WI), $3.2 \mu \mathrm{mol}$ of MgCl2 (Promega, Madison, WI), $0.8 \mu \mathrm{M}$ of deoxynucleoside 
triphosphates (Promega, Madison, WI), 2\% bovine serum albumin (Fischer Scientific Inc., Hampton, NH), $0.5 \mu \mathrm{M}$ (each) of forward and reverse primers (Integrated D NA Technologies, Coralville, IA), 0.5 units of Taqpolymerase (Promega, Madison, WI), and 200 ng of template D NA. The PCR protocol included a 5-min initial denaturation at $94^{\circ} \mathrm{C}$, 30 cycles of $92^{\circ} \mathrm{C}$ for $30 \mathrm{~s}, 55^{\circ} \mathrm{C}$ for $30 \mathrm{~s}$, and $72^{\circ} \mathrm{C}$ for 30 s, followed by $7 \mathrm{~min}$ at $72^{\circ} \mathrm{C}$. PCR products were combined, cleaned, and concentrated (100 $\mathrm{\mu l}$ to 60 $\mathrm{\mu l}$ ) using Q IAquick PCR Purification Kits (Q iagen Inc., Valencia, CA). Five $\mu \mathrm{l}$ of the PCR products were electrophoresed on $1.5 \%(\mathrm{w} / \mathrm{v})$ agarose gels to check for amplification of a band of the expected size ( 180 bp based on E. cdi positions 338 to 518). Additionally, the quantity of PCR products was analyzed using Q uantity One 1-D Analysis Software Version 4.5.1 (Bio-Rad Laboratories, Hercules, CA).

Fifteen $\mu \mathrm{l}$ ( $300 \mathrm{ng})$ of cleaned PCR product from each sample were loaded on a 8\% (w/ v) polyacrylamide gel (37.5:1 acrylamide:bisacrylamide) with a 40\% - 60\% denaturing gradient; where $100 \%$ denaturant contains $7 \mathrm{M}$ urea and $40 \%$ (v/ v) formamide in 0.5X tris-acetic acidEDTA buffer (TAE). Electrophoresis was performed for 4 minutes at $200 \mathrm{~V}$ and $60{ }^{\circ} \mathrm{C}$ to drive samples into wells and then 17 hours at $50 \mathrm{~V}$ and $60^{\circ} \mathrm{C}$ using the D Code Universal Mutation D etection System (Bio-Rad Laboratories, Hercules, CA). G els were silver-stained using the protocol of Caetano-Anolles and G resshoff (6) and scanned as tagged image file format (TIFF) files using a HP Scanjet 7400C scanner (Hewlett-Packard Co., Palo Alto, CA).

\section{DGGE Gel Analyses}

Bands were detected using the Q uantity O ne 1-D Analysis Software Version 4.5.1 (Bio-Rad Laboratories, Hercules, CA). Lanes were created manually, with anchor points at the top, middle, and bottom of the gel. The relative front calculation was set to follow lane. Background was subtracted from all lanes using a rolling disk with a radius of 15 pixels. Bands were detected manually using a band detection limit (intensity value 0.03 ) based on visual detection of faint bands on the gel. 


\section{Statistical Analyses}

All statistical analyses were performed using the SA S Statistical Software Package (SAS Institute Inc., Cary, NC). Differences between physical, chemical, and bacteriological measurements in winter as compared to summer were evaluated using Proc GLM with LSMeans and the tdiff option. Bacteriological data were $\log _{10}$ transformed to obtain geometric means prior to statistical analyses. Unless otherwise noted, significance was based on a P value of less than or equal to 0.05 .

For BIOLOG ® ECO plates total well color development (TWCD) was calculated as the sum of all blanked absorbance values for the 31 substrate wells. Average well color development (AWCD) was calculated as the mean of all blanked absorbance values for the 31 substrate wells. Substrate diversity $(H)$ was calculated as $H=-\quad p_{i} \ln _{i}$, where $p_{i}$ is the proportion of total microbial activity on a particular carbon source (ratio of each absorbance value to the TWCD). Substrate richness (S) was calculated as the number of wells with an absorbance value greater than 0.25 . Substrate richness per guild was calculated as the number of wells with an absorbance value greater than the AWCD within each guild. Substrate evenness (E) was calculated as $\mathrm{E}=\mathrm{H} / \ln (\mathrm{S})$, where $\mathrm{H}$ is substrate diversity and $\mathrm{S}$ is substrate richness. Principal component analysis (PCA) was performed on data normalized by dividing each substrate absorbance value by the AWCD $(15,16)$. This normalizes the data to account for differences in inoculum density of individual BIO LOG $®$ ECO plates. Pearson Product Moment Correlation (Pearson's correlation) was used to evaluate correlations between principal components and AWCD of each substrate.

Total lane intensity (TLI) was calculated as the sum of intensities of detected bands for each lane. Average band intensity (ABI) was calculated as the mean of intensities of detected band for each lane. Substrate diversity $(H)$ was calculated as $\mathrm{H}=-\quad \mathrm{p}_{\mathrm{i}} \log _{\mathrm{i}}$, where $\mathrm{p}_{\mathrm{i}}$ is the ratio of each detected band intensity to the TLI. Substrate richness (S) was calculated as the number of detected bands within each lane. Substrate evenness $(E)$ was calculated as $E=H / \log (S)$, where $\mathrm{H}$ is substrate diversity and $\mathrm{S}$ is substrate richness. PCA was performed on normalized data by dividing each band intensity value by the TLI. 


\section{RESULTS AND DISCUSSION}

Physical, Chemical, and Bacteriological Analyses

Physical and chemical parameters and microbial densities of wetland influent and wetland effluent are presented in Table 1. Passage of wastewater through the wetland resulted in a significant increase in $\mathrm{DO}$ and a significant decrease in $\mathrm{pH}$ and conductivity. O verall the system was able to significantly reduce $\mathrm{BOD}_{5}$ and TSS by $84.6 \%$ and $79.7 \%$, respectively. Treatment of the wastewater by the wetland resulted in a 3.2 log reduction of fecal coliforms and a $2.7 \log$ reduction of both E. cdi and enterococci. Additionally, the system was able to reduce total heterotrophs by $1.9 \mathrm{log}$. These results indicate a well functioning system, although a slight reduction in overall treatment efficacy was observed during winter months.

\section{Community-Level Physiological Profiles}

Community-level physiological profiles (CLPPs) have successfully been used to differentiate microbial communities in activated sludge and other larger scale wastewater treatment systems $(8,29,41,42,43)$. In a study of a municipal wastewater treatment system, Victorio et al. (43) used BIOLOG ${ }^{\circledR}$ to distinguish between heterotrophic microbial populations. Furthermore, the research suggested BIOLOG ${ }^{\circledR}$ might complement conventional testing as a means to detect changes in the microbial population due to factors such as temperature, ionic strength, effluent concentration, and inadvertent upsets, and also to measure recovery periods after system upsets. CLPPs generated by BIOLOG ${ }^{\circledR}$ rarely have been used to investigate constructed wetlands (20). Further investigations of heterotrophic bacteria in constructed wetlands with BIOLOG ${ }^{\circledR}$ may help to understand their role in the wastewater treatment process within these systems.

In the present study CLPP analyses were performed using BIO LO G $₫$ ECO plates to determine how wastewater passage through the wetland affected microbial functional diversity. Garland and Mills (15) first suggested the use of BIOLOG microtitre plates to generate community level physiological profiles (CLPPs) from the number and types of carbon 
substrates used by the heterotrophic bacterial community. Limitations to the CLPP approach have been extensively scrutinized and discussed $(17,22,34)$. The assay most probably characterizes only fast-growing, metabolically active, copiotrophic bacteria, and the environmental relevance of the carbon utilization profile obtained is questionable. However, the assay is relatively inexpensive, convenient, reproducible, and allows rapid indirect characterization of changes in microbial community structure. Studies suggest that changes in CLPP profiles indirectly reflect actual changes in the underlying microbial community $(38,5)$. The assay is complementary to molecular techniques for polyphasic community characterizations $(9,11,18,21)$.

CLPPs are potentially sensitive to large differences in initial inoculum density, since color development depends on rate of growth in the substrate wells. We used undiluted wastewater as a direct inoculum in the culture-independent approach to investigate spatial trends as wastewater passed through the wetland from influent to effluent. Other samples were sequentially filtered through 0.45 then $0.22 \mathrm{im}$ filters to fractionate the community by size for comparison of large (LC) and small (SC) cells. These filters were incubated on R2A medium for 48 hours prior to collection of cells (culture-dependent analyses). The culture-dependent approach allowed cell resuscitation and provided growth of a sufficient inoculum density from the low numbers of small cells originally present in effluent samples, allowing appropriate kinetics of color development for CLPP (Figure 2). Typically, BIO LO G ${ }^{\circledR}$ data are compared after a fixed incubation time when absorbance values for most substrates are increasing, but have not approached saturation (16). After inspection, data obtained at 54.5 hours for the LC and SC fractions (culture-dependent) and 75.5 hours for the TC fractions (cultureindependent) were chosen for further analysis (Figure 2).

Calculated CLPP indices are presented in Table 2. In order to eliminate weak responses from the calculations, an average absorbance value greater than 0.25 was required for a substrate to be positively utilized (17). TWCD , AWCD , and evenness of TC, LC and SC generally were higher in effluent compared to influent samples (Table 2). These data demonstrate the presence of an active microbial population in the effluent. Richness was high for all samples (26-30 substrates utilized) with the exception of TC, well \# 7 (22 substrates utilized, Table 2). 
The diversity indices calculated for TC and LC in influent and effluent samples were similar (3.14, 3.28, 3.26 and 3.35, respectively). Diversity indices calculated for influent SC (3.13) and effluent SC (3.30) were significantly different (Table 2). These data contrast those of Hench et al. (20) who used BIOLOG ${ }^{\circledR}$ G N plates, which contain 95 carbon substrates, and observed decreases in AWCD, richness, and diversity between influent and effluent of microcosm wetlands treating wastewater.

Diversity indices provide no information about the classes of substrates preferentially utilized by bacterial communities. BIOLOG ® ECO plates were originally designed for environmental studies and contain 31 carbon substrates relevant to growth of natural microbial communities (7). Therefore, it is not uncommon for many of these individual substrates to be positively utilized in an inoculated plate. Vahjen et al. (44) have defined a strongly utilized carbon substrate as one for which the absorbance was greater than the AWCD. D obranic and Zak (13) divided the carbon substrates in BIOLOG ${ }^{\circledR}$ ECO plates into substrate guilds. Combining these concepts, we examined average richness within substrate guilds for strongly utilized substrates (Table 3). O ne clear difference observed was the significant increase in utilization of carboxylic acids in effluent compared to influent LC and SC, but not TC fractions. In contrast amines/ amides were not strongly utilized by any fraction of the bacterial community examined. Carbohydrate, carboxylic acid, and polymer utilization generally increased in effluent LC compared to influent LC. Carboxylic acid and amino acid utilization was higher in effluent SC compared to influent SC. Utilization by the TC fraction increased for polymers and amines/ amides, and decreased for amino acids when influent was compared to effluent.

Principal component analysis (PCA) using normalized AWCD values for the LC and SC fractions of the bacterial communities is presented in Figure 3. Analysis showed principal component (PC) 1 accounted for $50.7 \%$ while PC2 accounted for $21.7 \%$ of the observed total variation. PC 1 was most positively correlated with á-ketobutyric acid $(r=0.9650)$ and most negatively correlated with á-D-lactose $(r=-0.8698)$. PC 2 was most positively correlated with $D$-cellobiose $(r=0.8327)$ and most negatively correlated with L-asparagine $(r=-0.7034)$. The two-dimensional plot of PC 1 and PC 2 separated the samples into two distinct groupings 
based primarily on position in the wetland, but not cell size (Figure 3). Influent communities differed from effluent communities, and SC and LC in each location exhibited similar substrate utilization patterns.

Principal component analysis (PCA) using normalized AWCD values for the TC fraction of the bacterial communities is presented in Figure 4. Compared with data presented in Figure 3, less of the total variation was accounted for in PC1 (29.2\%) and PC2 (17.9\%). PC 1 was most positively correlated with phenylethyl-amine $(r=0.8720)$ and was negatively correlated $D$ cellobiose $(r=-0.8936)$. PC 2 was most positively correlated with $D$-glucosaminic acid $(r=$ $0.9091)$ and negatively correlated with glycogen $(r=-0.6654)$. The two-dimensional plot of PC 1 and PC 2 generally separated the samples according to location within the wetland. The data suggest that the TC heterotrophic community of the influent was distinctly different than that of the effluent and that the TC heterotrophic community gradually changed during passage of the wastewater through the wetland.

\section{Denaturing G radient $\mathrm{G}$ el Electrophoresis Analyses}

D GGE has been used in several environments including soil $(18,27,30)$, surface water (36), and wastewater (24) and has proven to be a relatively simple approach to obtain profiles of microbial populations. These DGGE profiles can be linked to temporal or spatial differences in population structure that occur in response to environmental factors. Research using D GGE in wastewater has thus far been focused on pharmaceutical and metallurgic wastewater $(24,32)$, and activated sludge systems $(23,33)$.

Inocula used in CLPP analyses also were used for genetic examination of bacterial diversity using D G GE fingerprints generated from PCR amplification of community 16S rRNA genes. The D GGE profiles of the bacterial communities for LC and SC fractions using both culturedependent and culture-independent techniques are presented in Figure 5. DG GE analysis resulted in clear discernable banding patterns from both culture-independent and culturedependent samples. Major bands with intensities greater than 0.03 were identified as distinct operational taxonomic units (OTUs) and used in comparative analyses. Total OTUs (richness, 
Table 4) ranged from 17 to 37 among all samples. Only two OTUs were shared commonly among all samples. Five OTUs were shared among all culture-dependent analyses, and 8 OTUs were shared commonly among culture-independent analyses. Among all size classes and culturing methods, influent and effluent samples shared a number of common bands, ranging from 15 to 24 OTUs. The greatest difference between influent and effluent OTUs was 10, observed in the SC culture-dependent analyses. Bacterial diversity indices calculated for all samples are presented in Table 4. Bacterial diversity increased slightly in effluent LC compared to influent LC and decreased in effluent SC compared to influent SC using culturedependent analysis. Conversely, using culture-independent analysis diversity of effluent LC decreased and effluent SC increased compared to influent.

Unweighted UPGMA (based on presence or absence of bands) and weighted UPGMA (based on presence or absence of bands and band intensity) dendrograms constructed using Dice similarity matrix data for the PCR-amplified 16S rRNA genes resulted in different clustering patterns (Figure 6). The unweighted UPG MA dendrogram separated the data generally according to cell size into five distinct clusters (Figure 6a). When band intensity also was taken into consideration data separated into four distinct clusters according to cell size (LC or SC) and analysis method (CD or CI, Figure 6b). PCA analysis performed using absence or presence and normalized intensity values for each detected band showed separation similar to the weighted UPGMA dendrogram (Figure 7).

It is interesting, but perhaps not surprising, that CLPP using BIOLOG ${ }^{\circledR}$ and DGGE analyses resulted in contrasting views concerning the distribution of heterotrophic bacterial diversity in the wastewater wetland. CLPP is a measure of potential physiological diversity, not actual catabolic activity (34). Furthermore, CLPP is a selective enrichment since positive color development in the wells of BIO LOG ${ }^{\circledR}$ plates can be caused by active respiration and growth of a limited number of organisms. Much like CLPP using BIOLOG $®$, limitations of DGEE should also be considered when interpreting results. DGGE provides an estimate of actual genetic diversity of the dominant members of microbial communities, but also is subject to limitations such as the method of D NA extraction and PCR bias (28) and reveals nothing 
about the activity of microbial populations. Typically, cells must constitute at least $1 \%$ of the total microbial population to provide a visible band on D GGE gels (30). 


\section{CONCLUSIONS}

A research approach incorporating both traditional methodology and PCR-based molecular techniques was used to examine changes in heterotrophic community structure in wastewater treated by a constructed subsurface flow wetland. In this study, PCA of CLPPs grouped samples according to location in the wetland system suggesting redundant physiologies among the LC and SC fractions in the influent and effluent, but distinct potential functional diversity at each location (culture-dependent analysis). These data are consistent with CLPP patterns generated using the TC fraction that revealed a gradient of physiological potential from wetland influent to effluent. In contrast, PCA of DGGE profiles for the LC and SC fractions grouped according to cell size, rather than sample location. These data suggest that size fractionation resulted in distinct populations and that D NA from both populations could be recovered from samples throughout the wetland. However, simply because D NA was recovered it cannot be inferred that all members of these communities are viable and active throughout the wetland. Indeed, microbial enumerations in this research suggest significant reductions in viable bacteria due to passage through the wetland.

In future studies it may be interesting to couple reverse transcription PCR (RT-PCR) of rRNA with D G GE to better assess dominant active populations throughout the wetland. The working hypothesis would be that PCA generated from these methods would be more similar to those of CLPP, and would separate populations by both cell size and location. Further research should be conducted to evaluate the effect of environmental factors on CLPPs and DGGE profiles of the bacterial communities present in full-scale and on-site wastewater treatment systems. 
Table 1. Physical and chemical parameters and microbial densities of primary clarified wetland influent and wetland effluent over entire sampling period*

\begin{tabular}{|c|c|c|c|}
\hline Parameter & Influent & Effluent & $\begin{array}{l}\text { Percent removal/ } \\
\text { Log10 reduction }\end{array}$ \\
\hline$\overline{\mathrm{pH}}$ & $7.35(0.11)$ & $7.17(0.08)^{a}$ & \\
\hline Temperature $\left({ }^{\circ} \mathrm{C}\right)$ & $16.5(1.1)$ & $17.6(1.6)$ & \\
\hline $\mathrm{DO}\left(\mathrm{mg} \mathrm{L}^{-1}\right)$ & $1.82(0.18)$ & $2.30(0.26)^{\mathrm{a}}$ & \\
\hline Conductivity $\left(\mathrm{mS} \mathrm{cm}^{-1}\right)$ & $1.57(0.03)$ & $0.93(0.06)^{\mathrm{a}}$ & \\
\hline $\mathrm{BOD}_{5}\left(\mathrm{mg} \mathrm{L}^{-1}\right)$ & $206.5(15.3)$ & $37.7(8.4)^{a}$ & 84.6 \\
\hline $\mathrm{TSS}\left(\mathrm{mg} \mathrm{L}^{-1}\right)$ & $36.6(2.0)$ & $9.3(1.1)^{\mathrm{a}}$ & 79.7 \\
\hline Fecal coliforms ( $\log _{10}$ CFU $100 \mathrm{~mL}^{-1}$ ) & $5.6(0.16)$ & $2.4(0.13)^{\mathrm{a}}$ & 3.2 \\
\hline E. đi (Log ${ }_{10}$ CFU $\left.100 \mathrm{~mL}^{-1}\right)$ & $4.8(0.19)$ & $2.1(0.12)^{\mathrm{a}}$ & 2.7 \\
\hline Enterococci ( $\log _{10}$ CFU $\left.100 \mathrm{~mL}^{-1}\right)$ & $5.0(0.17)$ & $2.3(0.12)^{\mathrm{a}}$ & 2.7 \\
\hline Total heterotrophic bacteria $\left(\log _{10} \mathrm{CFU} \mathrm{mL}{ }^{-1}\right)$ & $6.9(0.09)$ & $5.0(0.10)^{\mathrm{a}}$ & 1.9 \\
\hline
\end{tabular}

* Mean (standard error in parentheses) of samples $(\mathrm{n}=23)$ (3 replicates/ sample) collected over entire sampling period.

${ }^{\mathrm{a}}$ Indicates effluent was significantly different than influent $(\mathrm{P}<0.05)$. 
Table 2. Bacterial functional diversity indices as determined with BIO LOG ${ }^{\circledR}$ ECO plates

\begin{tabular}{|c|c|c|c|c|c|c|}
\hline Cell Fraction & Sample & $\mathrm{TWCD}^{\mathrm{a}, \mathrm{f}}$ & $\mathrm{AWCD}^{\mathrm{b}, \mathrm{f}}$ & Richness $^{\mathrm{c}, \mathrm{f}}$ & Diversity $^{\mathrm{d}, \mathrm{f}}$ & Evenness ${ }^{\mathrm{e}, \mathrm{f}}$ \\
\hline \multicolumn{7}{|c|}{ Culture Dependent Analysis } \\
\hline \multicolumn{7}{|l|}{ Large Cells } \\
\hline & Influent & $32.8 \mathrm{~b}$ & $1.06 \mathrm{~b}$ & $30 \mathrm{a}$ & $3.28 \mathrm{a}$ & $0.96 \mathrm{~b}$ \\
\hline & Effluent & $43.3 \mathrm{a}$ & $1.40 \mathrm{a}$ & $30 \mathrm{a}$ & $3.35 \mathrm{a}$ & $0.98 \mathrm{a}$ \\
\hline \multicolumn{7}{|l|}{ Small Cells } \\
\hline & Influent & $32.9 \mathrm{~b}$ & $1.06 \mathrm{~b}$ & $27 \mathrm{~b}$ & $3.13 \mathrm{~b}$ & $0.96 \mathrm{~b}$ \\
\hline & Effluent & $41.9 \mathrm{a}$ & $1.35 \mathrm{a}$ & $29 \mathrm{ab}$ & $3.30 \mathrm{a}$ & $0.98 \mathrm{a}$ \\
\hline \multicolumn{7}{|c|}{ Culture Independent Analysis } \\
\hline \multicolumn{7}{|l|}{ Total Cells } \\
\hline & Influent & $36.7 \mathrm{~b}$ & $1.18 \mathrm{~b}$ & $26 \mathrm{c}$ & $3.14 \mathrm{c}$ & $0.96 \mathrm{c}$ \\
\hline & Well 2 & $40.4 \mathrm{ab}$ & $1.30 \mathrm{ab}$ & $30 \mathrm{a}$ & $3.34 \mathrm{a}$ & $0.99 \mathrm{a}$ \\
\hline & Well 3 & $42.3 \mathrm{a}$ & $1.36 \mathrm{a}$ & $28 \mathrm{abc}$ & $3.22 \mathrm{bc}$ & $0.97 \mathrm{bc}$ \\
\hline & Well 4 & $41.0 \mathrm{ab}$ & $1.32 \mathrm{ab}$ & $29 \mathrm{ab}$ & $3.32 \mathrm{ab}$ & $0.99 \mathrm{a}$ \\
\hline & Well 5 & $39.7 \mathrm{ab}$ & $1.28 \mathrm{ab}$ & $27 \mathrm{bc}$ & $3.24 \mathrm{abc}$ & $0.98 \mathrm{ab}$ \\
\hline & Well 6 & $44.1 \mathrm{a}$ & $1.42 \mathrm{a}$ & $29 \mathrm{ab}$ & $3.27 \mathrm{ab}$ & $0.97 \mathrm{abc}$ \\
\hline & Well 7 & $27.5 \mathrm{c}$ & $0.89 \mathrm{c}$ & $22 \mathrm{~d}$ & $2.88 \mathrm{~d}$ & $0.94 \mathrm{~d}$ \\
\hline & Effluent & $41.0 \mathrm{ab}$ & $1.32 \mathrm{ab}$ & $28 \mathrm{ab}$ & $3.26 \mathrm{abc}$ & $0.97 \mathrm{abc}$ \\
\hline
\end{tabular}

${ }^{a}$ Total well color development $($ TWCD) $=$ mean sum of blanked absorbance values from triplicate analysis.

${ }^{\mathrm{b}}$ Average well color development $(\mathrm{AWCD})=\mathrm{TWCD} / 31$.

${ }^{\mathrm{c}}$ Richness $=$ mean number of wells greater than 0.25 from triplicate analysis.

${ }^{\mathrm{d}}$ Diversity $=\mathrm{H}=$ - sum (pi*lnpi), where $\mathrm{pi}=$ mean of each absorbance value $/ \mathrm{TWCD}$.

${ }^{\mathrm{e}}$ Evenness $=\mathrm{E}=\mathrm{H} / \ln (\mathrm{S})$, where $\mathrm{H}$ is diversity and $\mathrm{S}$ is richness.

${ }^{\mathrm{f}}$ Mean values in each column within culture-dependent and within culture-independent analysis followed by the same letter are not significantly different $(\mathrm{P}<0.05)$ as determined by Tukey's Studentized Range (HSD) Test. 
Table 3. Richness within substrate guilds as determined by strongly utilized substrates with BIOLOG ® ECO plates

\begin{tabular}{|c|c|c|c|c|c|c|c|}
\hline Cell Fraction & Sample & Carbohydrates $^{\mathrm{a}}$ & Carboxylic Acids ${ }^{\mathrm{a}}$ & Polymers ${ }^{\mathrm{a}}$ & Amino Acids ${ }^{\mathrm{a}}$ & Amines/Amides ${ }^{\mathrm{a}}$ & Misc. $^{\text {a }}$ \\
\hline \multicolumn{8}{|c|}{ Culture Dependent Analysis } \\
\hline \multicolumn{8}{|l|}{ Large Cells } \\
\hline & Influent & $4 \mathrm{~b}$ & $4 \mathrm{~b}$ & $2 \mathrm{~b}$ & $2 \mathrm{a}$ & $0 \mathrm{a}$ & $1 \mathrm{a}$ \\
\hline & Effluent & $6 \mathrm{ab}$ & $6 \mathrm{a}$ & $4 \mathrm{ab}$ & $2 \mathrm{a}$ & $0 \mathrm{a}$ & $1 \mathrm{a}$ \\
\hline \multicolumn{8}{|l|}{ Small Cells } \\
\hline & Influent & $5 \mathrm{ab}$ & $4 \mathrm{~b}$ & $3 a b$ & $2 \mathrm{a}$ & $0 \mathrm{a}$ & $2 a$ \\
\hline & Effluent & $5 \mathrm{a}$ & $6 a$ & $3 a b$ & $3 \mathrm{a}$ & $0 \mathrm{a}$ & $1 \mathrm{a}$ \\
\hline \multicolumn{8}{|c|}{ Culture Independent Analysis } \\
\hline Total Cells & & & & & & & \\
\hline & Influent & $6 \mathrm{a}$ & $4 \mathrm{ab}$ & $3 a b$ & $2 \mathrm{a}$ & $0 \mathrm{c}$ & $1 \mathrm{a}$ \\
\hline & Well 2 & $6 a$ & $5 \mathrm{ab}$ & $3 \mathrm{~b}$ & $2 \mathrm{a}$ & $0 \mathrm{c}$ & $1 \mathrm{a}$ \\
\hline & Well 3 & $6 \mathrm{a}$ & $5 \mathrm{ab}$ & $3 a b$ & $3 \mathrm{a}$ & $0 \mathrm{c}$ & $1 \mathrm{a}$ \\
\hline & Well 4 & $6 \mathrm{a}$ & $6 \mathrm{a}$ & $3 a b$ & $2 \mathrm{a}$ & $2 a b$ & $1 \mathrm{a}$ \\
\hline & Well 5 & $6 a$ & $6 a$ & $3 a b$ & $3 a$ & $2 a$ & $1 \mathrm{a}$ \\
\hline & Well 6 & $6 \mathrm{a}$ & $4 a b$ & $3 a b$ & $3 \mathrm{a}$ & $1 \mathrm{ab}$ & $2 a$ \\
\hline & Well 7 & $5 a$ & $2 \mathrm{~b}$ & $3 \mathrm{~b}$ & $1 \mathrm{a}$ & $1 \mathrm{bc}$ & $2 a$ \\
\hline & Effluent & $6 \mathrm{a}$ & $4 a b$ & $4 \mathrm{a}$ & $3 a$ & $1 \mathrm{abc}$ & $1 \mathrm{a}$ \\
\hline
\end{tabular}

${ }^{a}$ Mean values in each column within culture-dependent and within culture-independent analysis followed by the same letter are not significantly different $(\mathrm{P}<0.05)$ as determined by Tukey's Studentized Range (HSD) Test. 
Table 4. Bacterial diversity indices as determined with DGGE profiles

\begin{tabular}{|c|c|c|c|c|c|c|}
\hline Cell Fraction & Sample & $\operatorname{TLI}^{\mathrm{a}}$ & $\mathrm{ABI}^{\mathrm{b}}$ & Richness $^{c}$ & Diversity $^{\mathrm{d}}$ & Evenness $^{\mathrm{e}}$ \\
\hline \multicolumn{7}{|c|}{ Culture Dependent Analysis } \\
\hline \multicolumn{7}{|l|}{ Large Cells } \\
\hline & Influent & 2.99 & 0.11 & 28 & 1.37 & 0.95 \\
\hline & Effluent & 5.47 & 0.19 & 29 & 1.40 & 0.96 \\
\hline \multicolumn{7}{|l|}{ Small Cells } \\
\hline & Influent & 5.75 & 0.16 & 37 & 1.48 & 0.94 \\
\hline & Effluent & 4.10 & 0.24 & 17 & 1.16 & 0.94 \\
\hline \multicolumn{7}{|c|}{ Culture Independent Analysis } \\
\hline Large Cells & & & & & & \\
\hline & Influent & 5.97 & 0.21 & 28 & 1.38 & 0.95 \\
\hline & Effluent & 5.18 & 0.21 & 25 & 1.32 & 0.95 \\
\hline \multicolumn{7}{|l|}{ Small Cells } \\
\hline & Influent & 3.05 & 0.15 & 20 & 1.22 & 0.94 \\
\hline & Effluent & 2.79 & 0.12 & 23 & 1.26 & 0.93 \\
\hline
\end{tabular}

${ }^{a}$ Total lane intenstiy $(\mathrm{TLI})=$ sum of normalized intensity values from detected bands.

${ }^{\mathrm{b}}$ Average band intensity $(\mathrm{ABI})=\mathrm{TLI} / \mathrm{number}$ of detected bands.

${ }^{\mathrm{c}}$ Richness $=$ number of detected bands (intensity greater than 0.03).

${ }^{\mathrm{d}}$ Diversity $=\mathrm{H}=-$ sum $(\mathrm{pi} *$ logpi), where pi $=$ each detected band intensity/TLI.

${ }^{\mathrm{e}}$ Evenness $=\mathrm{E}=\mathrm{H} / \mathrm{ln}(\mathrm{S})$, where $\mathrm{H}$ is diversity and $\mathrm{S}$ is richness. 


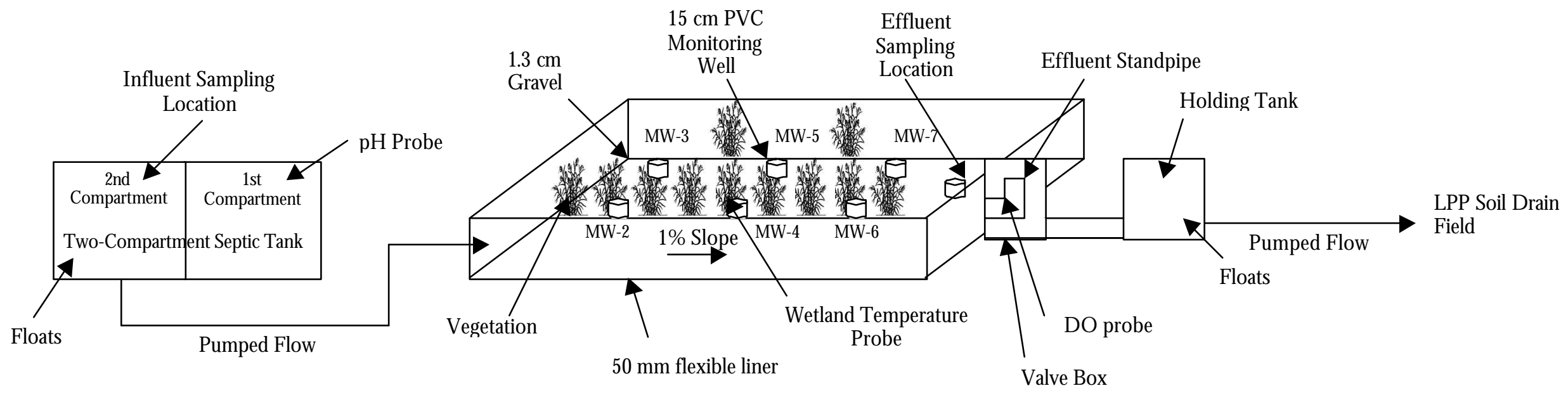

Figure 1. G eneral schematic of the constructed subsurface flow wetland system 


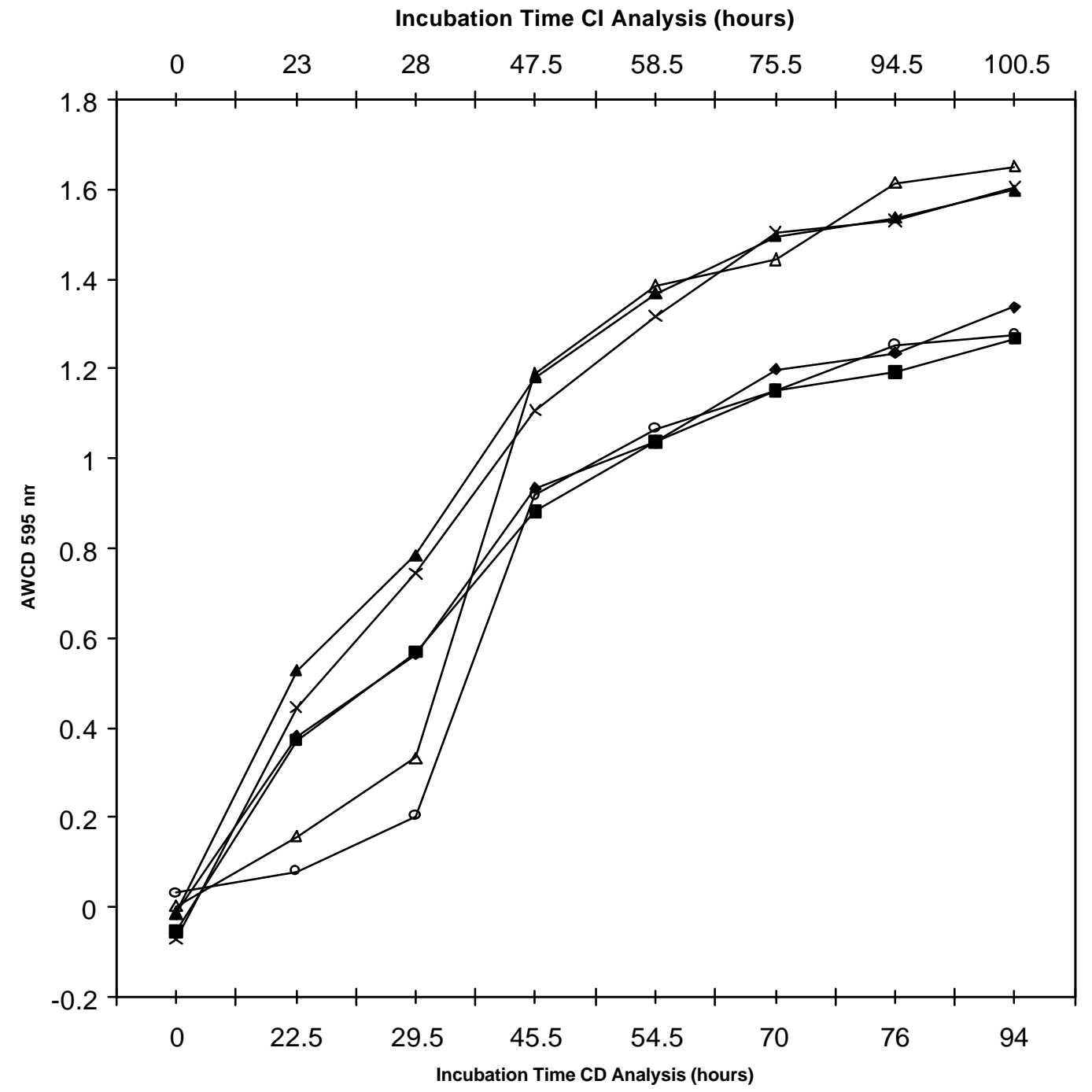

Figure 2. Average well color development (AWCD) from BIOLOG $₫$ ECO plates for the total cell (TC) fraction using culture-independent (CI) analysis and the large cell (LC) and small cell (SC) fractions using culture-dependent analysis. Symbols are as follows: ( ) Influent TC CI; ( ) Effluent TC CI; ( ) Influent LC CD; ( ) Effluent LC CD; ( ) Influent SC CD; (x) Effluent SC CD. (Note: Some symbols are obscured by symbols at several points on the figure.) 


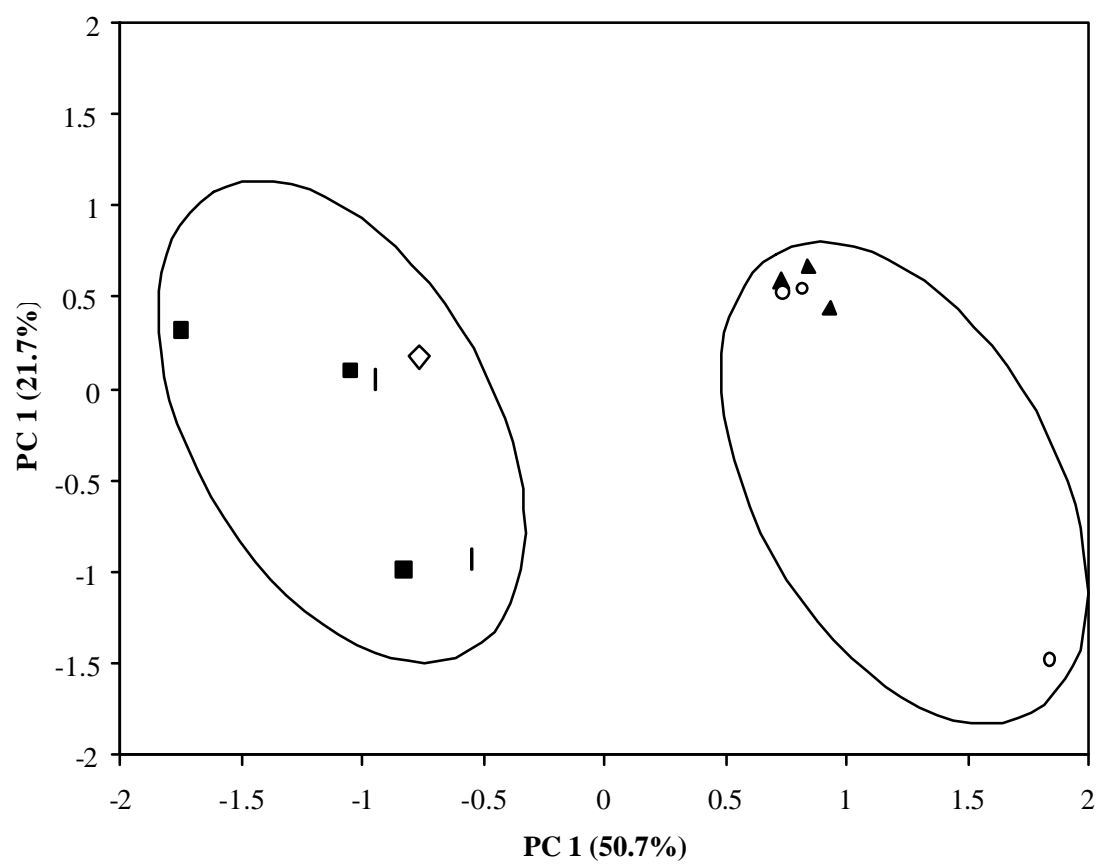

Figure 3. Principal component analysis based on normalized AWCD (average absorbance value for each substrate divided by AWCD) from BIOLOG ${ }^{\circledR}$ ECO plates. Values in parenthesis indicate the proportion of the total variation accounted for by each principal component. Symbols are as follows: ( ) Influent LC CD ; ( ) Influent SC CD ; ( ) Effluent LC CD ; (o) Effluent SC CD. 


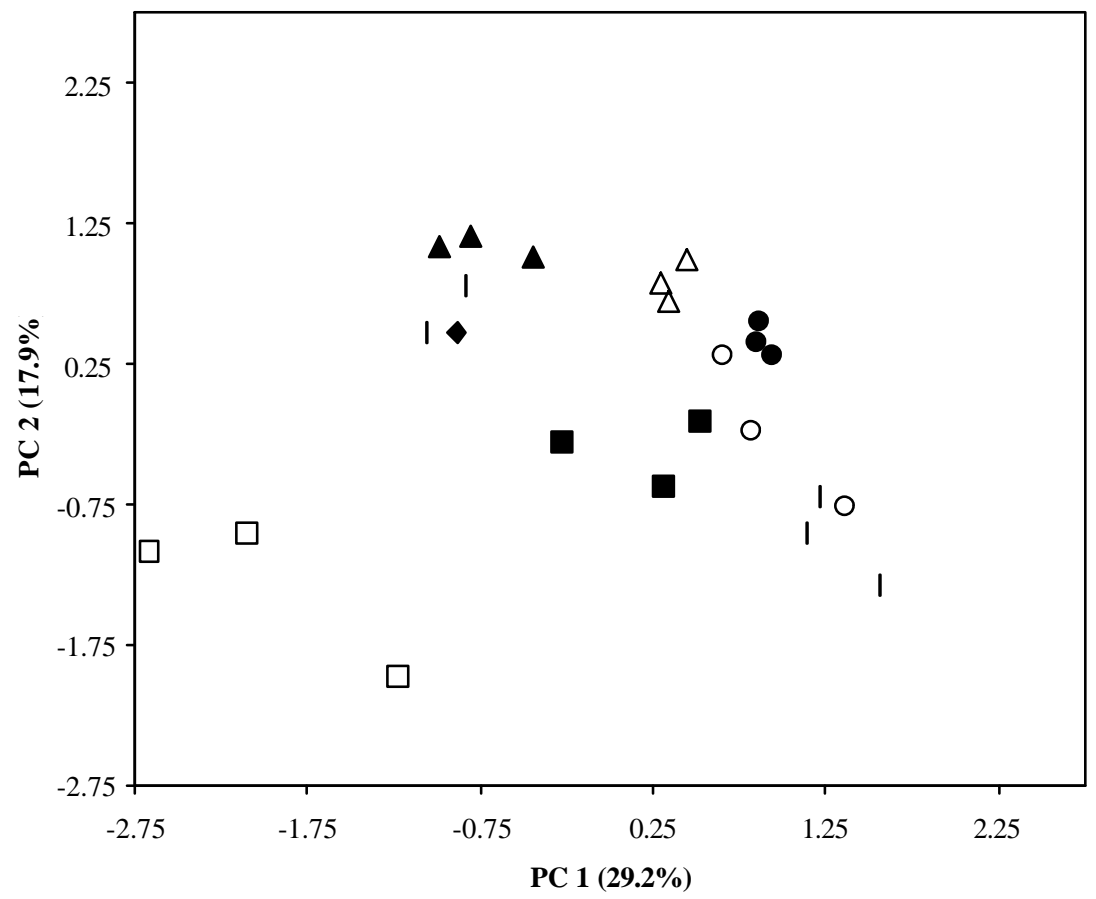

Figure 4. Principal component analysis based on normalized AWCD (average absorbance value for each substrate divided by AWCD) from BIOLOG ® ECO plates for the total cell (TC)

fraction using culture-independent (CI) analysis. Values in parenthesis indicate the proportion of the total variation accounted for by each principal component. Symbols are as follows: ( ) Influent TC CI; ( ) Well 2 TC CD; ( ) Well 3 TC CD; ( ) Well 4 TC CD; ( ) Well 5 TC CD; ( ) Well 6 TC CD; ( ) Well 7 TC CD; ( ) Effluent TC CI. 


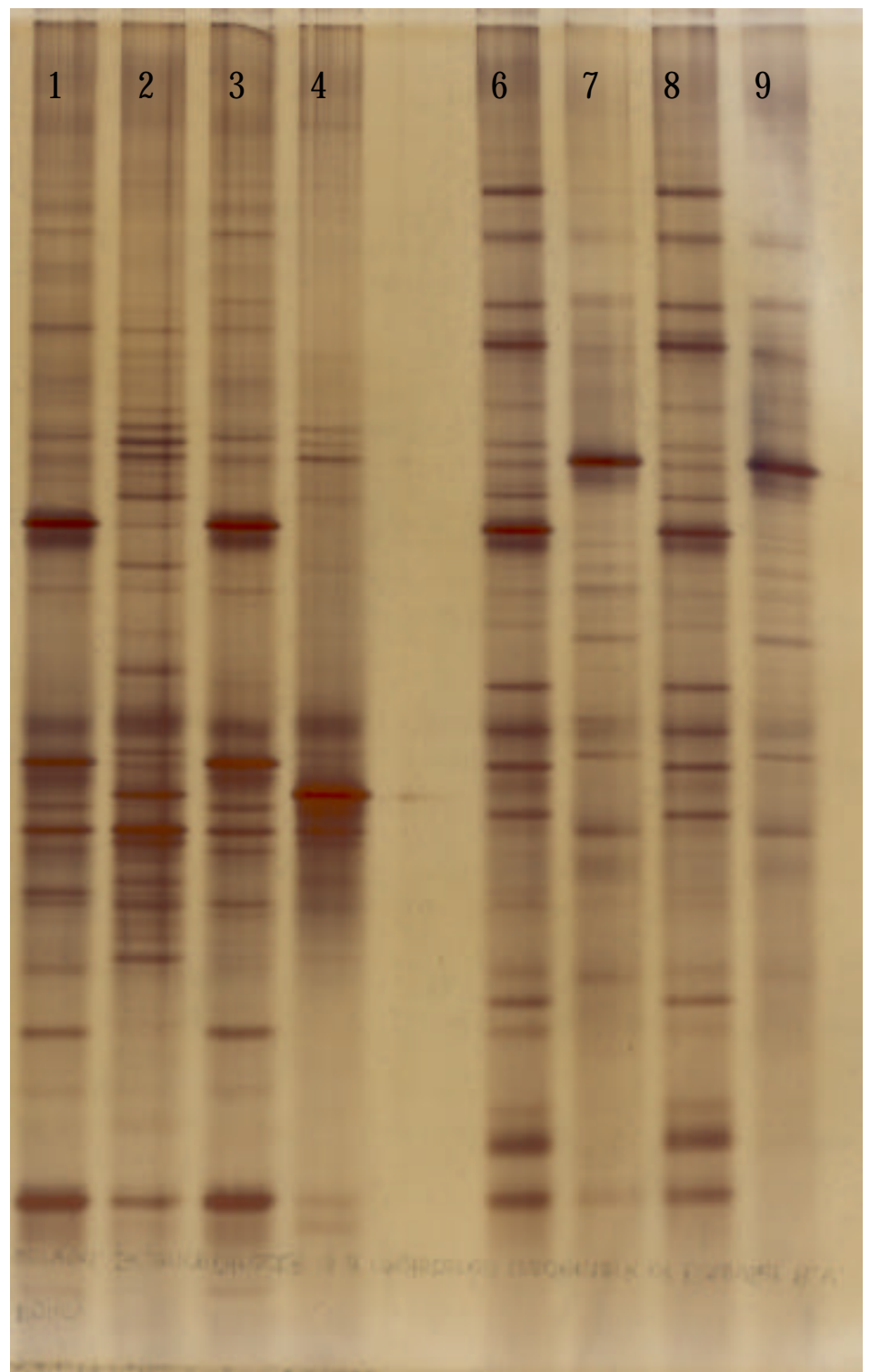

Figure 5. DGGE analysis of PCR-amplified 16S rRNA genes from the LC and SC fractions of the wetland bacterial communities. The figure shows profiles of Influent LC CD (lane 1); Influent SC CD (lane 2); Effluent LC CD (lane 3); Effluent SC CD (lane 4); Influent LC CI (lane 6); Influent SC CI (lane 7); Effluent LC CI (lane 8); Effluent SC CI (lane 9). 


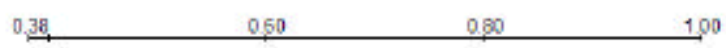

(a)

Effluent SC CD (lane 4)
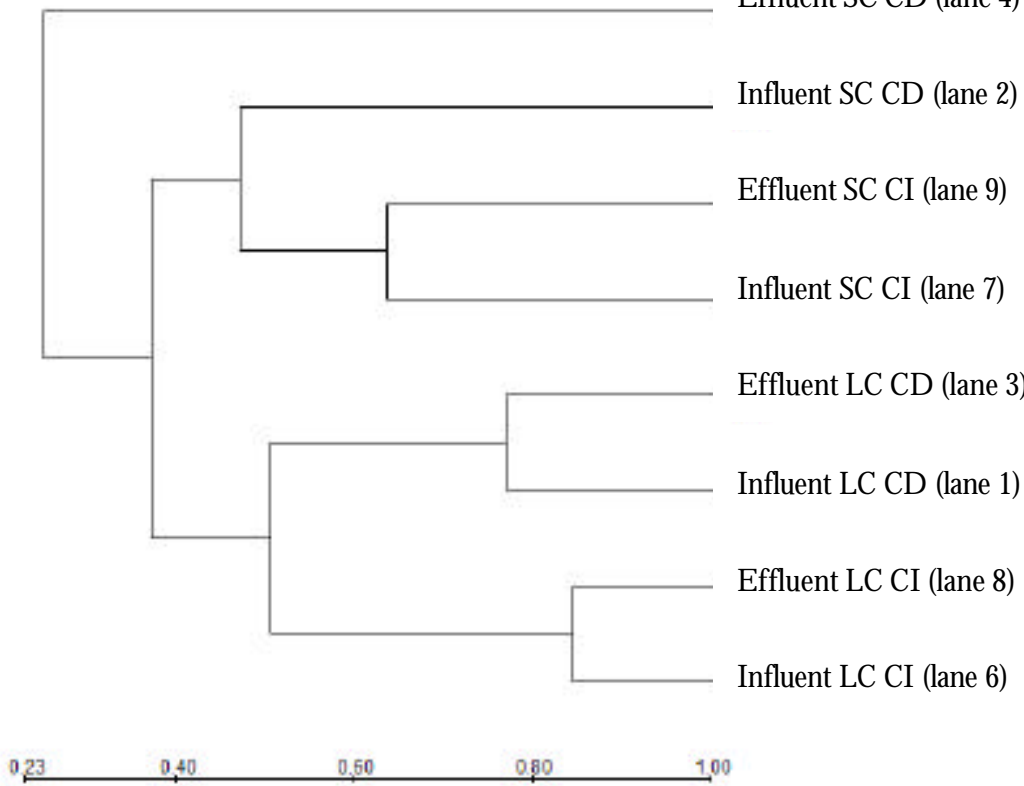

(b)

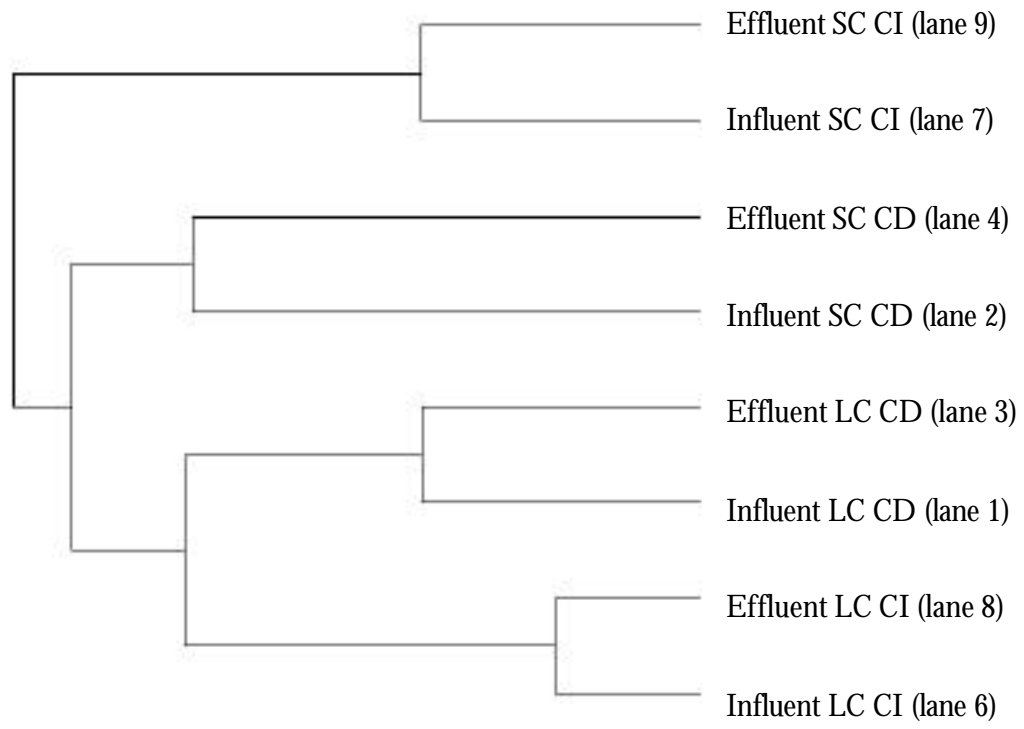

Figure 6. Unweighted (a) UPGMA and weighted (b) UPGMA dendrograms constructed using dice similarity matrix generated from DGGE profiles of PCR-amplified 16S rRNA genes from the LC and SC fractions of the wetland bacterial communities. Lane numbers represent the following samples: Influent LC CD (lane 1); Influent SC CD (lane 2); Effluent LC CD (lane 3); Effluent SC CD (lane 4); Influent LC CI (lane 6); Influent SC CI (lane 7); Effluent LC CI (lane 8); Effluent SC CI (lane 9). 


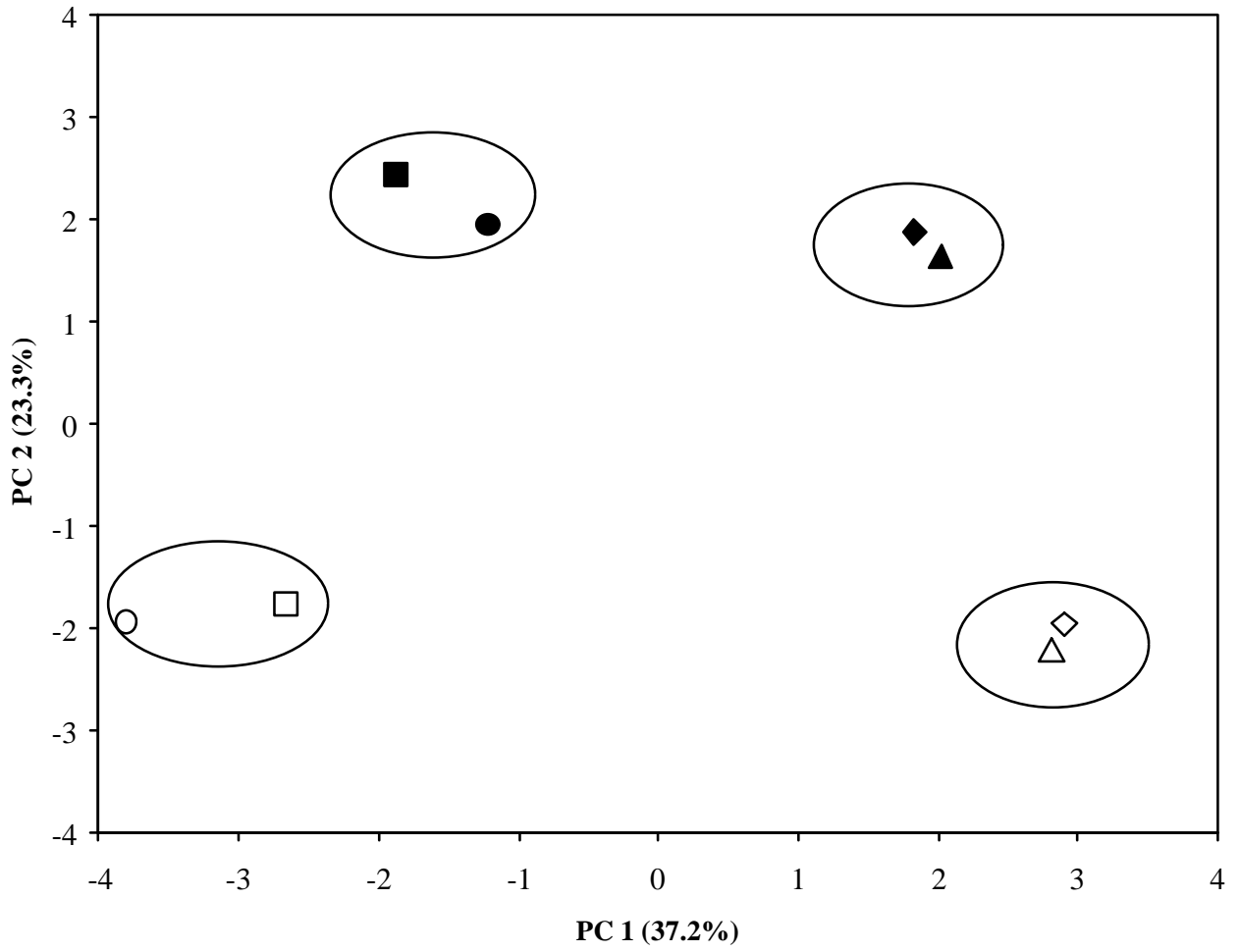

Figure 7. Principal component analysis based on normalized band intensity (band intensity value for each band divided by total lane intensity) from D G GE analysis of PCR-amplified 16S rRNA genes. Values in parenthesis indicate the proportion of the total variation accounted for by each principal component. Symbols are as follows: ( ) Influent LC CD ; ( ) Effluent LC CD; ( ) Influent SC CD; ( ) Effluent SC CD; （ ) Influent LC CI; ( ) Effluent LC CI; ( ) Influent SC CI; ( ) Effluent SC CI. 
Reference List

1 Amann, R., H. Lemmer, and M. Wagner. 1998. Monitoring the community structure of wastewater treatment plants: a comparison of old and new techniques. FEMS Microbiology Ecology 25:205-215.

2 APH A (American Public Health Association). Standard Methods for the Examination of Water and Wastewater, 20th ed. American Public Health Association Inc., New York, N.Y.

3 Bastian, R. K. and D. A. Hammer. 1989. The use of constructed wetlands for wastewater treatment and recycling, p. 59-68. InConstructed Wetlands for Water Q uality Treatment. CRC Press, Boca Raton, FL.

4 Batchelor, A. and P. Loots. 1997. A critical evaluation of a pilot scale subsurface flow wetland: 10 years after commissioning. Water Science and Technology 35:337-343.

5 Bossio, D. A. and K. M. Scow. 1995. Impact of carbon and flooding on the metabolic diversity of microbial communitites in soils. Applied and Environmental Microbiology 61:4043-4050.

6 Caetano-Anolles, G. and P. M. Gresshoff. 1994. Staining nucleic acids with silver: An alternative to radioisotopic and fluorescent labeling. Promega Notes Magazine 45:13-20.

7 Campbell, C. D., S. J. Grayston, and D. J. Hirst. 1997. Use of rhizosphere carbon sources in sole carbon source tests to discriminate soil microbial communities. Journal of Microbial Methods 30:30-41.

8 Cicek, N., J. Macomber, J. Davel, M. T. Suidan, J. Audic, and P. Genestet 2001. Effect of solids retention time on the perfromance and biological characteristics of a membrane bioreactor. Water Science and Technology 43 :43-50.

9 Crecchio, C., A. Gelsomino, R. Ambrosoli, J. L. Minati, and P. Ruggiero. 2004. Functional and molecular responses of soil microbial communities under differing soil management practices. Soil Biology \& Biochemistry 36:1873-1883.

10 Dahab, M. F. and R. Y. Surampalli. 2001. Subsurface-flow constructed wetlands treatment in the plains: five years of experience. Water Science and Technology 44:375380.

11 Dawson, S. L., J. C. Fry, and B. N. Dancer. 2002. A comparative evaluation of five typing techniques for determining the diversity of fluorescent pseudomonads. Journal of Microbiological Methods 50:9-22.

12 De Fede, K. L. and A. J. Sexstone. 2001. Differential response of size-fractionated soil bacteria in BIOLOG (R) microtitre plates. Soil Biology and Biochemistry 33 :1547-1554.

13 Dobranic, J. K. and J. C. Zak 1999. A microtiter plate procedure for evaluating fungal 
functional diversity. Mycologia 91:756-765.

14 Ebeling, J., S. Tsukuda, J. Hankins, and C. Solomon. Washington DC, USA. Evaluation and real-time monitoring of a recirculating sand and peat filter. Third NSF International Symposium of Small D rinking Water and Wastewater Systems .

15 Garland, J. L. and A. L. Mills. 1991. Classification and characterization of heterotrophic microbial communities on the basis of patterns of community-level solecarbon-source-utilization. Applied and Environmental Microbiology 57:2351-2359.

16 Garland, J. L. 1996. Analytical approaches to the characterization of samples of microbial communities using patterns of potential C source utilization. Soil Biology and Biochemistry 28:213-221.

17 Garland, J. L. 1997. Analysis and interpretation of community-level physiological profiles in microbial ecology. FEMS Microbiology Ecology 24:289-300.

18 Girvan, M. S., J. Bullimore, J. N. Pretty, A. M. Osbom, and A. S. Ball. 2003. Soil type is the primary determinant of the composition of the total and active bacterial communities in arable soils. Applied and Environmental Microbiology. 69:1800-1809.

19 Haller, C. M., S. Rolleke, D. Vybiral, A. Witte, and B. Velimirov. 2000. Investigation of 0.2 um filterable bacteria from the western Mediterranean Sea using a molecular approach: dominance of potential starvation forms. FEMS Microbiology Ecology 31:153-161.

20 Hench, K. R., A. J. Sexstone, and G. K. Bissonnette. 2004. Heterotrophic community-level physiological profiles of domestic wastewater following treatment by small constructed subsurface flow wetlands. Water Environment Research 76:468-473.

21 Juck, D., T. Charles, L. G. L. G. Whyte, and C. W. Greer. 2000. Polyphasic microbial community analysis of petroleum hydrocarbon-contaminated soils from two northern Canadian communities. FEMS Microbiology Ecology 33:241-249.

22 Konopka, A., L. Oliver, and R. F. J. R. Turco. 1998. The use of carbon substrate utilization patterns in environmental and ecological microbiology. Microbial Ecology 35:103-115.

23 Kreuzinger, N., A. Famleitner, G. Wandi, R. Homek, and R. Mach 2003. Molecular biological methods (D G GE) as a tool to investigate nitrification inhibition in wastewater treatment. Water Science and Technology 47:165-172.

24 LaPara, T. M., C. H. Nakatsu, L. Pantea, and J. E. Alleman 2000. Phylogenetic analysis of bacterial communities in mesophilic and thermophilic bioreactors treating pharmaceutical wastewater. Applied Environmental Microbiology. 66:3951-3959.

25 Leonard, K. M. Ph. D. P. E. 2000. Analysis of residential subsurface flow constructed wetlands performance in northern Alabama. Small Flows Q uarterly 1:34-39. 
26 Lillis and G. K. Bissonnette. 2001. D etection and characterization of filterable heterotrophic bacteria from rural groundwater supplies. Letters in Applied Microbiology 32:268-272.

27 McCaig, A. E., L. A. Glover, and J. I. Prosser. 1999. Molecular analysis of bacterial community structure and diversity in unimproved and improved upland grass pastures. Applied Environmental Microbiology. 65:1721-1730.

28 McCaig, A. E., L. A. Glover, and J. I. Prosser. 2001. Numerical analysis of grassland bacterial community structure under different land management regimens by using $16 \mathrm{~S}$ ribosomal D NA sequence data and denaturing gradient gel electrophoresis banding patterns. Applied Environmental Microbiology. 67:4554-4559.

29 Muller, E., K. Kriebitzsch, P. A. Wilderer, and S. Wuertz. 2002. Community structure of micro- and macroflocs in pin-point sludge and the influence of sludge age and potassium addition on microfloc formation. Water Science and Technology 46:405412.

30 Muyzer, G., E. de Waal, and A. Uitterlinden. 1993. Profiling of complex microbial populations by denaturing gradient gel electrophoresis analysis of polymerase chain reaction-amplified genes coding for $16 \mathrm{~S}$ rRNA. Applied Environmental Microbiology. 59:695-700.

31 Neralla, S., R. W. Weaver, B. J. Lesikar, and R. A. Persyn. 2000. Improvement of domestic wastewater quality by subsurface flow constructed wetlands. Bioresource Technology 75:19-25.

32 N oda, N., S. Yoshie, S. T suneda, A. H irata, and Y. Inamori 2002. PCR-D G GE analysis of denitrifying bacteria in a metallurgic wastewater treatment process. Water Science and Technology 46:333-336.

33 Oerther, D. B., J. Pemthaler, A. Schramm, R. Amann, and L. Raskin. 2000. Monitoring precursor $16 \mathrm{~S}$ rRNAs of acinetobacter spp. in activated sludge wastewater treatment systems. Applied Environmental Microbiology. 66:2154-2165.

34 Preston-Mafham, J., L. Boddy, and P. F. Randerson. 2002. Analysis of microbial community functional diversity using sole-carbon-source utilisation profiles - a critique. FEMS Microbiology Ecology 42:1-14.

35 Rutz, B. A. and T. L. Kieft. 2004. Phylogenetic characterization of dwarf archaea and bacteria from a semiarid soil. Soil Biology \& Biochemistry 36:825-833.

36 Sekiguchi, H., M. Watanabe, T. Nakahara, B. Xu, and H. Uchiyama 2002. Succession of bacterial community structure along the Changjiang river determined by denaturing gradient gel electrophoresis and clone library analysis. Applied Environmental Microbiology. 68:5142-5150.

37 Shirey, J. J. and G. K. Bissonnettte. 1991. D etection and identification of groundwater bacteria capable of escaping entrapment on 0.45-um-pore-size membrane filters. Applied 
and Environmental Microbiology 57:2251-2254.

38 Smalla, K., U. Wachtendorf, H. Heuer, W. Liu, and L. Forney. 1998. Analysis of BIO LO G GN substrate utilization patterns by microbial communities. Applied and Environmental Microbiology. 64:1220-1225.

39 Steer, D., L. Fraser, J. Boddy, and B. Seibert 2002. Efficiency of small constructed wetlands for subsurface treatment of single-family domestic effluent. Ecological Engineering 18:429-440.

40 U.S. Environmental Protection Agency. 1993. Subsurface flow constructed wetlands for wastewater treatment: a technology assessment. O ffice of Water, USEPA, Washington, DC.

41 van H eerden, J., MM. Ehlers, and TE. Cloete. 2001. BIO LO G for the determination of microbial diversity in activated sludge systems. Water Science and Technology 43:8390.

42 van Heerden, J., C. Korf, MM. Ehlers, and TE. Cloete. 2002. BIO LOG for the determination of diversity in microbial communities. Water SA 28:29-35.

43 Victorio, L., K. A. Gilbride, D. G. Allen , and S. N. Liss. 1996. Phenotypic fingerprinting of microbial communities in wastewater treatment systems. Water Research 30:1077-1086.

44 W. Vahjen, J. Munch, and C. C. Tebbe. 1995. Carbon source utilization of soil extracted microorganisms as a tool to detect the effects of soil supplemented with genetically engineered and non-engineered corynebacteruim glutamicum and a recombinant peptide at the community level. FEMS Microbiology Ecology 18:317-328. 
Appendix 1. Photographs of Constructed Subsurface Flow Wetland Research Site 


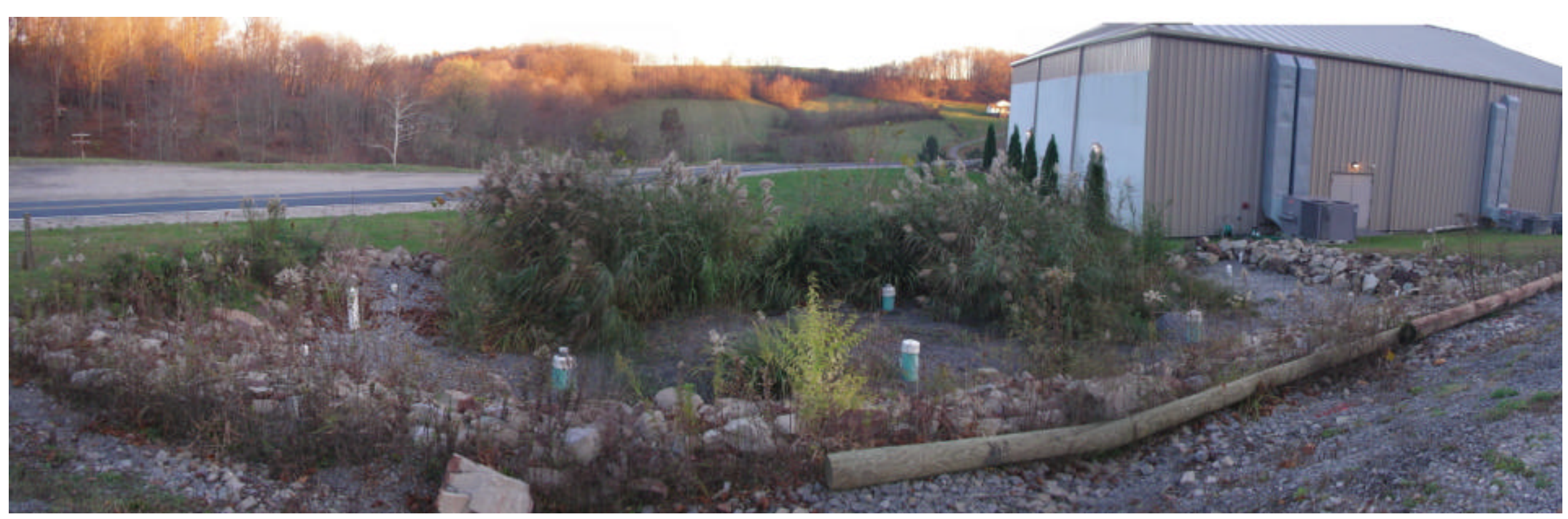

Figure 1. Study Site - Constructed subsurface flow gravel wetland treating wastewater from a multi-user facility. 


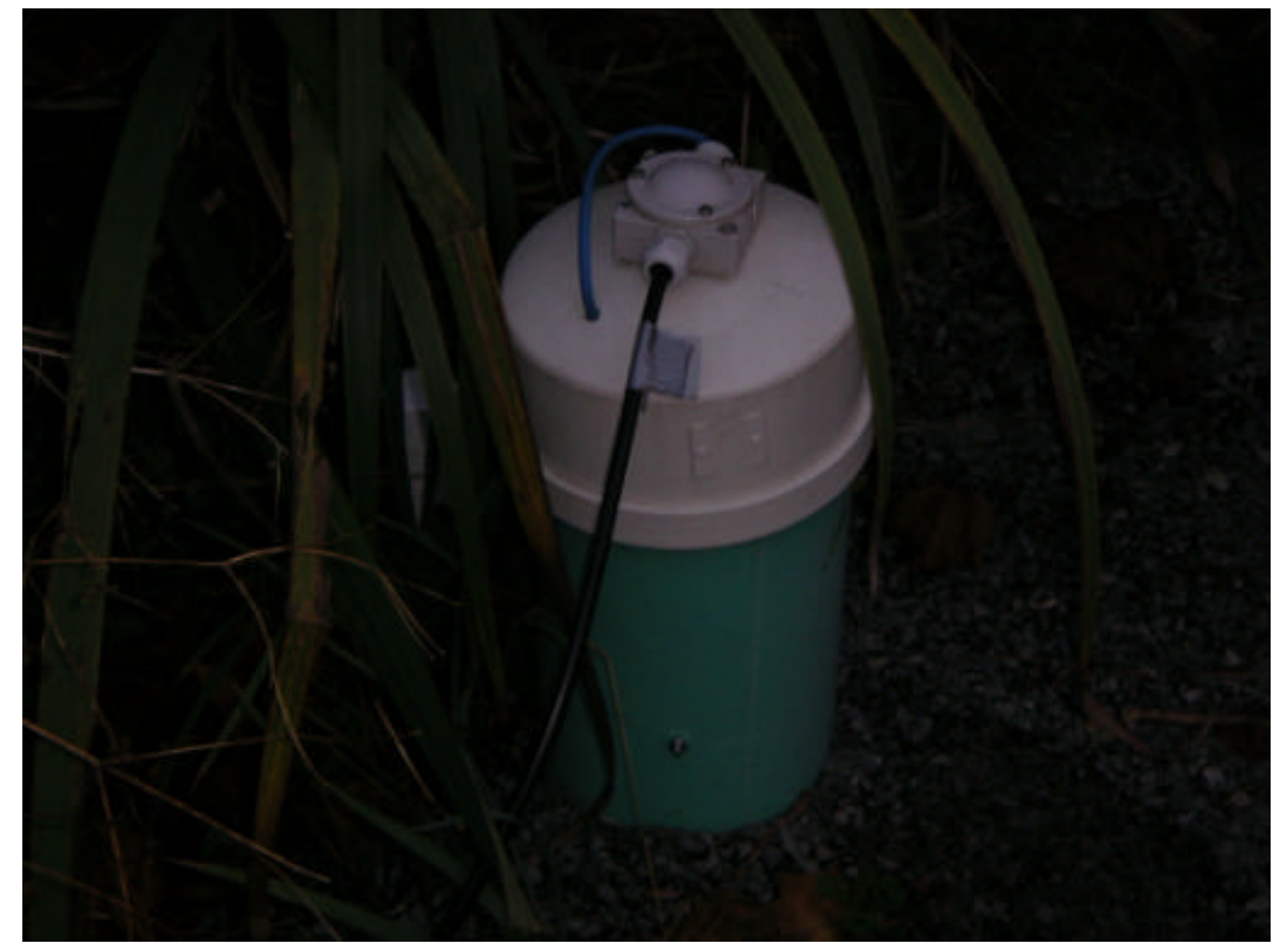

Figure 2. $15 \mathrm{~cm}$ diameter PVC temporary monitoring well installed in wetland used for sample collection. Note electrical wiring leading into well for water temperature probe located in well. 


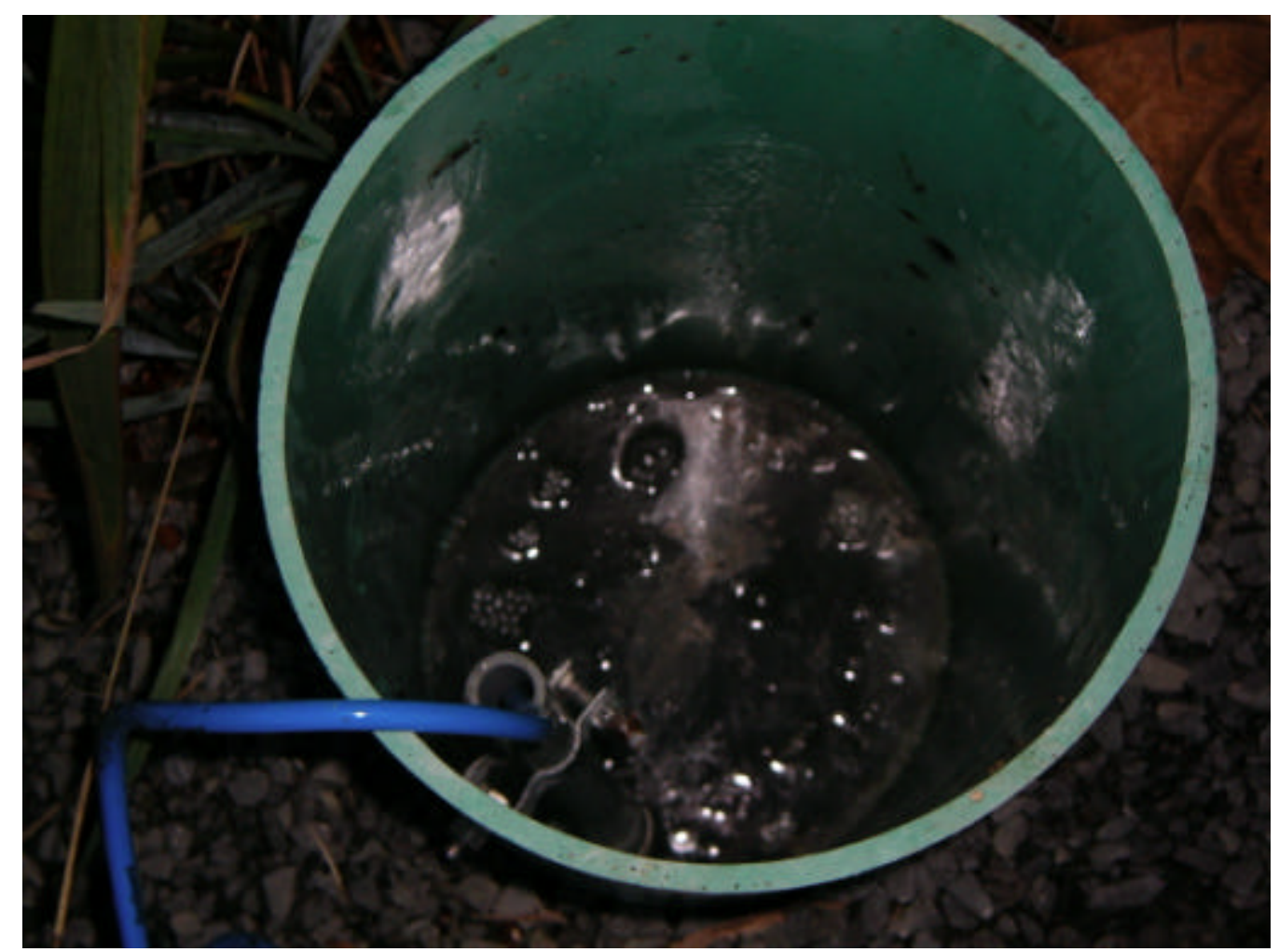

Figure 3. Inside of temporary monitoring well and view of temperature probe inside well. 

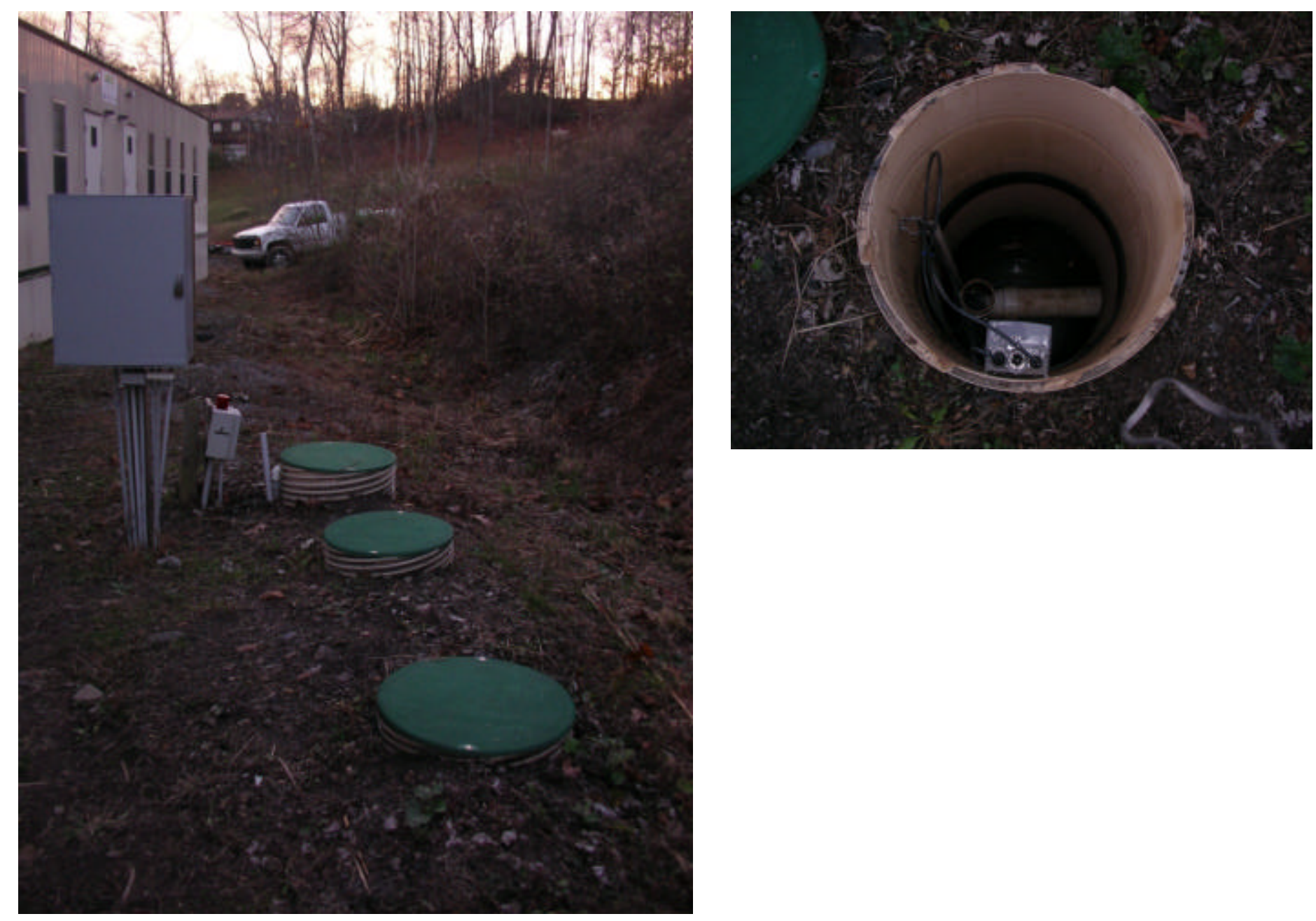

Figure 4. View of lids to two-compartment septic tank and telemetry panel. View of inside of first compartment of septic tank (top right). 


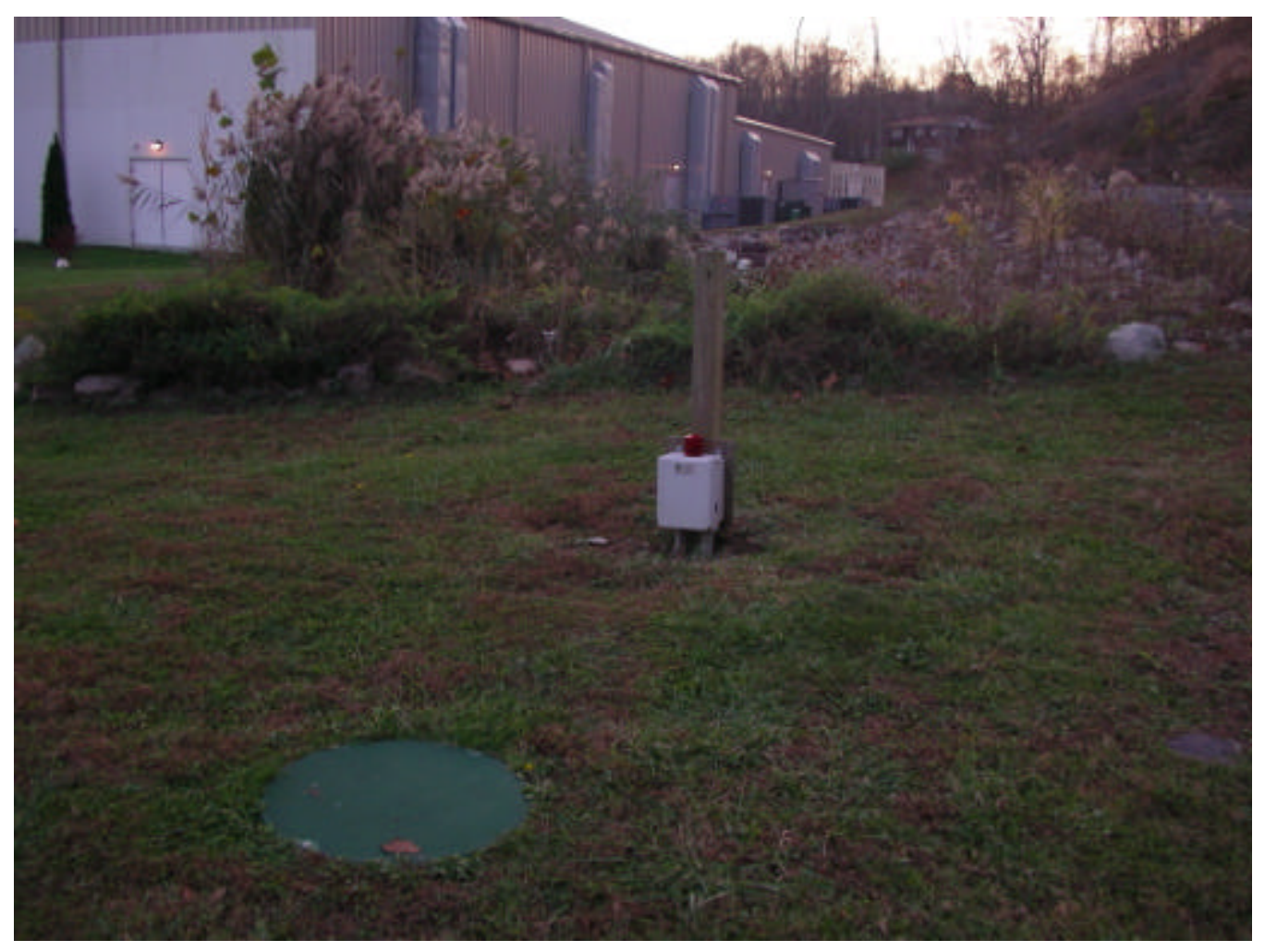

Figure 5. View of wetland system from the discharge end. Lid of pump tank chamber (doses to the soil drain field) in the foreground. 


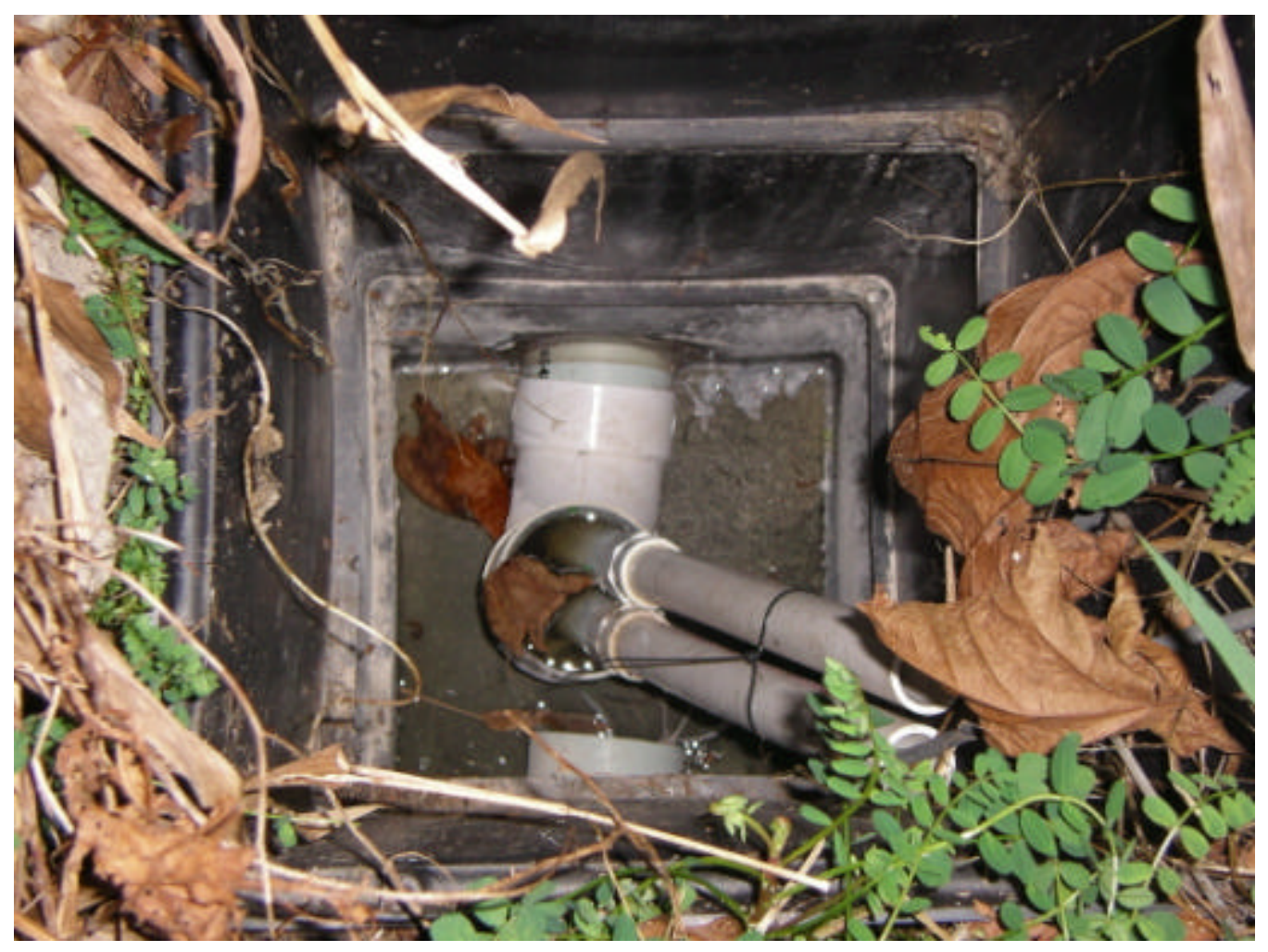

Figure 6. View of inside of discharge box located at discharge end of wetland. Elbow shaped standpipe regulates water level of wetland. Two oxygen probes are installed in the standpipe. 

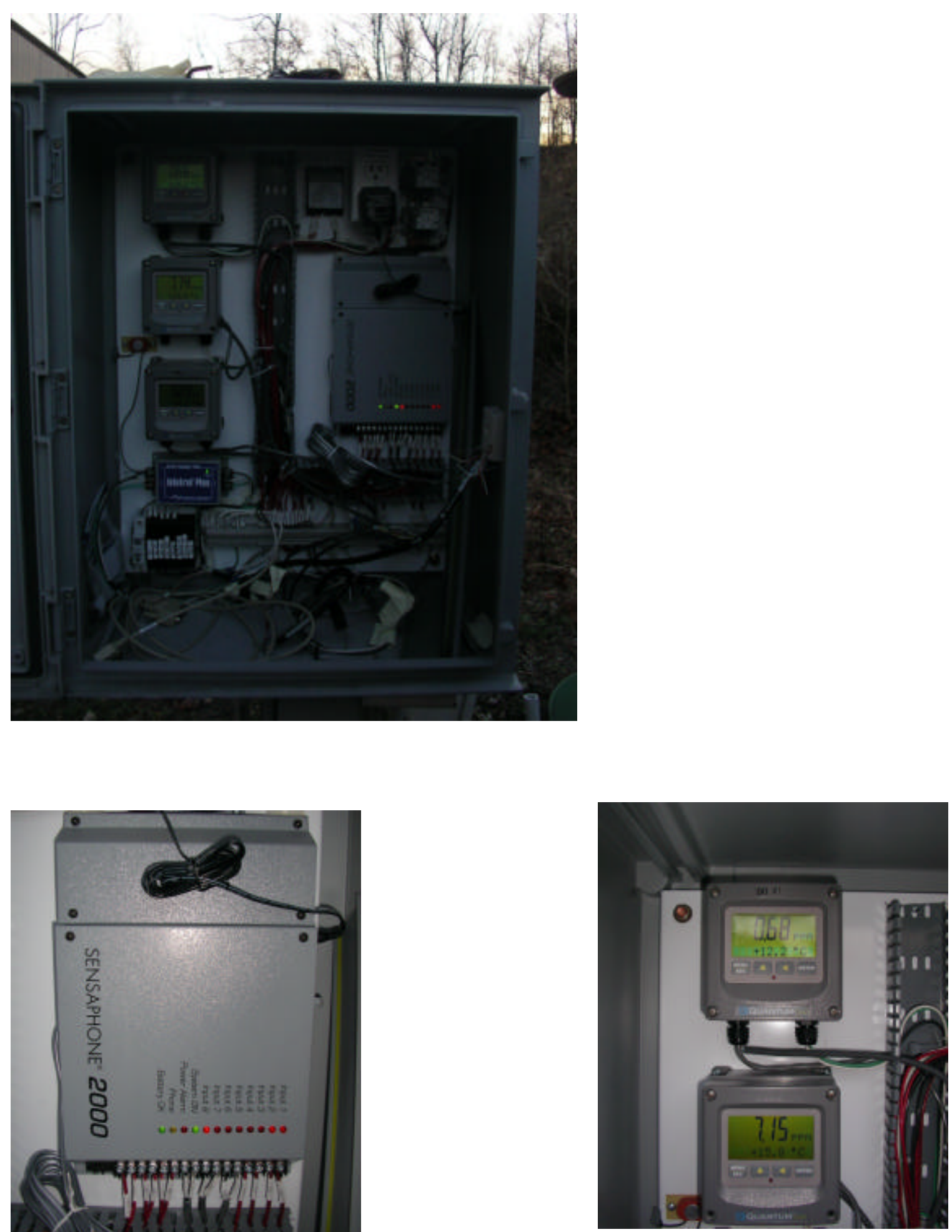

Figure 7. Inside of telemetry panel. Zoomed in view of D O meters (middle) and Sensaphone ${ }^{\circledR}$ 2000 (right) which is used to download telemetry readings via a telephone line to a computer at WVU. 